Review

\title{
In Vitro and in Vivo Antitumoral Effects of Combinations of Polyphenols, or Polyphenols and Anticancer Drugs: Perspectives on Cancer Treatment
}

\author{
Massimo Fantini ${ }^{1}$, Monica Benvenuto ${ }^{1}$, Laura Masuelli ${ }^{2}$, Giovanni Vanni Frajese ${ }^{3}$, \\ Ilaria Tresoldi ${ }^{1}$, Andrea Modesti ${ }^{1}$ and Roberto Bei ${ }^{1, *}$
}

1 Department of Clinical Sciences and Translational Medicine, University of Rome "Tor Vergata", Rome 00133, Italy; E-Mails: kurk84@gmail.com (M.F.); monicab4@hotmail.it (M.B.); ilaria3soldi@hotmail.com (I.T.); modesti@med.uniroma2.it (A.M.)

2 Department of Experimental Medicine, University of Rome "Sapienza", Rome 00164, Italy; E-Mail: Laura.masuelli@uniroma1.it

3 Dipartimento di Scienze Motorie, Umane e della Salute, Università di Roma, Foro Italico, Rome 00194, Italy; E-Mail: frajese@hotmail.com

* Author to whom correspondence should be addressed; E-Mail: bei@med.uniroma2.it; Tel.: +39-06-7259-6522; Fax: +39-06-7259-6506.

Academic Editor: Sanjay K. Srivastava

Received: 13 February 2015 / Accepted: 15 April 2015 / Published: 24 April 2015

\begin{abstract}
Carcinogenesis is a multistep process triggered by genetic alterations that activate different signal transduction pathways and cause the progressive transformation of a normal cell into a cancer cell. Polyphenols, compounds ubiquitously expressed in plants, have anti-inflammatory, antimicrobial, antiviral, anticancer, and immunomodulatory properties, all of which are beneficial to human health. Due to their ability to modulate the activity of multiple targets involved in carcinogenesis through direct interaction or modulation of gene expression, polyphenols can be employed to inhibit the growth of cancer cells. However, the main problem related to the use of polyphenols as anticancer agents is their poor bioavailability, which might hinder the in vivo effects of the single compound. In fact, polyphenols have a poor absorption and biodistribution, but also a fast metabolism and excretion in the human body. The poor bioavailability of a polyphenol will affect the effective dose delivered to cancer cells. One way to counteract this drawback could be combination treatment with different polyphenols or with polyphenols and other anti-cancer drugs, which can lead to more effective antitumor effects than treatment using only one
\end{abstract}


of the compounds. This report reviews current knowledge on the anticancer effects of combinations of polyphenols or polyphenols and anticancer drugs, with a focus on their ability to modulate multiple signaling transduction pathways involved in cancer.

Keywords: polyphenols; bioavailability; carcinogenesis; anticancer drugs; nanotechnology

\section{Introduction}

Polyphenols, a large group of compounds ubiquitously expressed in plants, are secondary metabolites that play various roles in host defense against pathogens, ultraviolet radiation, and signal transduction [1]. Polyphenols are present in foods and beverages of plant origin (fruits, vegetables, cereals, herbs, spices, legumes, nuts, olives, chocolate, tea, coffee, and wine) and are the most abundant antioxidants in the human diet [2]. Epidemiological studies have shown that a diet rich in polyphenols can prevent a wide variety of human diseases. Polyphenols show many beneficial effects on human health including antimicrobial, anti-inflammatory, antiviral, anticancer, and immunomodulatory activities [3-8].

Carcinogenesis is a multistep process that causes the progressive transformation of a normal cell into a cancer cell [9]. Malignant transformation is due to the overexpression or hyperactivation of genes that promote cell survival and proliferation (oncogenes) or to the loss of expression or functional inactivation of genes that control cell growth (tumor suppressor genes). As a result, while normal cells are responsive to exogenous stimuli that control their growth and survival, cancer cells can grow in the absence of exogenous signals and become unresponsive to negative regulators of growth and survival. In addition, overexpression of growth factors and/or their receptors leads to constant activation of downstream signaling pathways, promoting the growth and survival of cancer cells [9-12].

Signal transduction pathways involved in carcinogenesis often interact with each other, enhancing oncogenic signals that trigger the malignant phenotype of cells [3,10]. For example, cross-talk between the signaling pathways mediated by avian erythroblastosis oncogene B (ErbB) receptors,

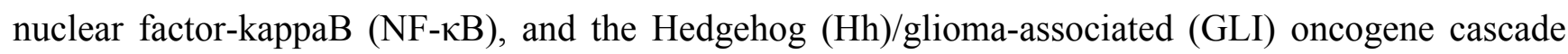
(HH/GLI) plays an important role in neoplastic transformation [3]. Because they are able to modulate the signal transduction pathways involved in carcinogenesis, plant derivatives have promising potential for counteracting tumor growth $[3,13,14]$.

The main drawback to using polyphenols as anticancer agents is their poor bioavailability in the human body, which may hinder their in vivo effects, especially when used singly $[15,16]$. One approach to counteracting this effect may be combination treatment with several polyphenols or with polyphenols and anticancer drugs. This report reviews current knowledge on the anticancer effects of combinations of polyphenols or polyphenols and anticancer drugs, with a focus on their ability to modulate multiple signaling transduction pathways involved in carcinogenesis. 


\section{Classification of Polyphenols}

Polyphenols are widely distributed in plant-derived foods. They comprise a large variety of compounds that have a characteristic structure of at least one aromatic ring bearing one or more hydroxyl groups. Polyphenols are classified according to the number of phenol rings that they contain and by the structural elements that bind these rings to one another. The main classes of polyphenols are flavonoids, phenolic acids, stilbenes, and lignans [1,15] (Figure 1).

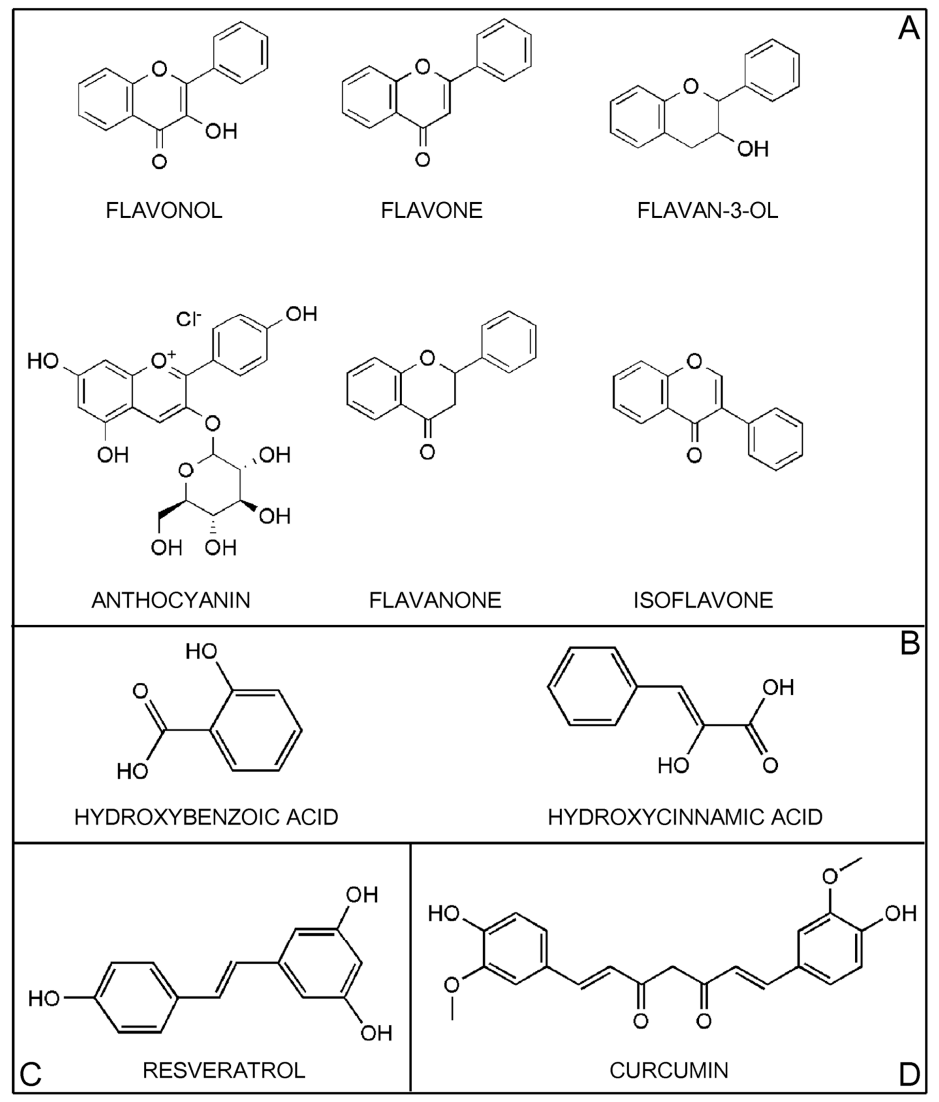

Figure 1. Structure of the major classes of polyphenols. Panel A: Flavonoids; Panel B: Phenolic acids; Panel C: Stilbenes. The figure shows the main member, resveratrol; Panel D: Other polyphenols. The figure shows curcumin.

\subsection{Flavonoids}

Flavonoids, the most abundant polyphenols in our diet, are formed from phenylalanine through a biosynthetic process involving the shikimic acid and acylpolymalonate pathways [17]. Flavonoids consist of 15 carbon atoms with 2 aromatic rings (A- and B-rings) connected by a 3-carbon bridge that binds with 1 oxygen and 2 carbons of the A-ring, forming a third 6-carbon ring (C-ring) [18]. Flavonoids are further classified into subclasses defined by different functional groups and levels of oxidation in the C-ring, and by different connections between the B- and C-rings. Variations between compounds within a subclass consist of different substituents on the A- and B-rings [4] (Figure 1, Panel A).

As well as the different subclasses of flavonoids, worldwide, dietary intake of flavonoids is highly variable. From a dietary standpoint, the most important food-based subclasses of flavonoids are flavonols, 
flavones, flavan-3-ols, anthocyanins, flavanones, and isoflavones. The flavonoid subclasses dihydroflavonols, flavan-3,4-diols, chalcones, dihydrochalcones, and aurones are minor components of our diet [4].

\subsubsection{Flavonols}

Flavonols are present in plants in glycosylated form. The sugar component, most commonly glucose or rhamnose, is on the 3-position of the C-ring (Figure 1, Panel A). The main flavonols are quercetin, kaempferol, and myricetin, found mostly in fruits, edible plants, wine, and tea [1]. Although flavonols represent the most abundant flavonoids found in foods, their daily intake is generally low. Several studies have estimated a mean daily intake of $21.4 \mathrm{mg} /$ day (the Netherlands), $22.4 \mathrm{mg} / \mathrm{day}$ (Italy), $16.8 \mathrm{mg} /$ day (Denmark), $18.7 \mathrm{mg} /$ day (Spain), $5.4 \mathrm{mg} /$ day (Finland), $19.4 \mathrm{mg} /$ day (Greece), $27.4 \mathrm{mg} /$ day (UK), $16.4 \mathrm{mg} /$ day (Japan), and $12.9 \mathrm{mg} /$ day (USA) [4].

\subsubsection{Flavones}

The chemical structure of flavones may have a wide range of substitutions, including hydroxylation, methylation, $O$ - and $C$-alkylation, and glycosylation. Flavones are present in plants mainly as 7-O-glycosides [15] (Figure 1, Panel A). Their most abundant representatives in foods are apigenin (parsley, celery, onion, garlic, pepper, chamomile tea) and luteolin (thai chili, onion leaves, celery). Less abundant flavones include tangeretin and nobiletin (Citrus fruits), baicalein and wogonin (Scutellaria), and chrysin (Passiflora). Estimated daily intake of flavones is very low (0.3-1.6 mg/day) [4].

\subsubsection{Flavan-3-Ols}

Flavan-3-ols, the most chemically complex subclass of flavonoids, contain a hydroxyl group in the 3-position of the C-ring (Figure 1, Panel A). They exist in monomeric, oligomeric, and polymeric forms and are not glycosylated in foods. The simplest monomers are (+)-catechin and its isomer $(-)$-epicatechin, whose hydroxylation generates $(+)$-gallocatechin and $(-)$-epigallocatechin. $(-)$-epicatechin-3-O-gallate and (-)-epigallocatechin-3-O-gallate (EGCG) are formed through an additional esterification with gallic acid in the 3-position of the C-ring. Proanthocyanidins are dimers, oligomers, and polymers of catechins and are subdivided into types A, B, and $\mathrm{C}$. The most common proanthocyanidins found in plants are procyanidins B1, B2, B3, and B4 [1,15]. Flavan-3-ols are found mainly in fruits, berries, cereals, nuts, chocolate, red wine, and tea. Estimated daily intake is very high (12-189.2 mg/day) [4].

\subsubsection{Anthocyanins}

Anthocyanins are water-soluble pigments mainly present as glycosides of their aglycone form (anthocyanidin) [19] (Figure 1, Panel A). There are more than 550 anthocyanins in nature. They vary according to the number of hydroxyl groups and degree of methylation in the aglycone molecule, the number and position of sugars linked to the aglycone molecule, and the number and nature of aliphatic or aromatic acids linked to these sugars [4]. The most abundant anthocyanins are cyanidin, pelargonidin, delphinidin, peonidin, petunidin, and malvidin. Their main food sources are berries, cherries, red grapes and currants, red wines, blood oranges, the black varieties of soybeans, rice, beans, and the red varieties 
of onions, potatoes, and cabbage [11]. In the U.S., estimated daily intake of anthocyanins is high compared to other flavonoids (180-215 mg/day) [11].

\subsubsection{Flavanones}

Flavanones are non-planar flavonoids found mainly in citrus fruits, where they occur mainly as mono- and diglycosides or, less frequently, in aglycone form (Figure 1, Panel A). The most important aglycone flavanones are naringenin and hesperetin. The correspondent glycated forms are neohesperidosides such as naringin (naringenin-7-O-neohesperidoside) and neohesperidin (hesperetin-7- $O$-neohesperidoside), and rutinosides, such as narirutin (naringenin-7- $O$-rutinoside) and hesperidin (hesperetin-7-O-rutinoside) [15,20]. Hesperetin, naringenin, neohesperidin and naringin are abundant in oranges, grapefruit and tomatoes. The main food sources of hesperidin and narirutin are sweet orange, lemon, mandarin and grapefruit [20]. The estimated mean dietary intake of flavanones is highest in Europe (20.4-50.6 mg/day) and relatively lower in the U.S. (14.4 mg/day) [4].

\subsubsection{Isoflavones}

Isoflavones are classified as phytoestrogens due to structural similarities with estrogens, particularly 17-ß-estradiol, that confer pseudohormonal activity [18,21] (Figure 1, Panel A). Daidzein, genistein, and glyciten are the most common members of this subclass. They are found mainly in soybeans and soy products, which have the highest levels of isoflavones, and in leguminous plants [22]. In soy products, isoflavones occur as aglycones (genistein and daidzein) or glycosides (genistin and daidzin), depending on how the soy products are processed [22]. Estimated mean dietary intake of isoflavones is very low in Europe and the U.S. (0.1-1.2 mg/day) and higher in Japan and China, where consumption of soy products is more common [4].

\subsubsection{Minor Subclass of Flavonoids}

Chalcones, dihydrochalcones, aurones, dihydroflavonols, and flavan-3,4-diols make up a minor subclass of flavonoids. The main food sources of chalcones are tomatoes, licorice, shallots, and bean sprouts. Dihydrochalcones (phloretin) occur exclusively in apples and apple products. Aurones (aureusidin) are isomers of flavones that have a limited presence in vegetables and fruits. Dihydroflavonols and flavan-3,4-diols are biosynthetic intermediates of the flavonols and anthocyanins [4].

\subsection{Phenolic Acids}

Phenolic acids are derivatives of benzoic acid and cinnamic acid [1]. Hydroxybenzoic acids have a $\mathrm{C}_{6}-\mathrm{C}_{1}$ structure, are found in few edible plants, and do not have high nutritional value (Figure 1, Panel B). Members of this subclass are protocatechuic acid and gallic acid, the commonest phenolic acid. In its non-sugar galloyl ester form, its main dietary sources are grapes, wine, green and black teas, and mangoes. Gallic acid is also the biosynthetic precursor of hydrolysable tannins (gallotannins and ellagitannins), where it occurs as complex sugar esters. Gallotannins are found in mangoes; ellagitannins occur in red fruits such as strawberries, raspberries, and blackberries $[1,15]$. 
Hydroxycinnamic acids have a $\mathrm{C}_{6}-\mathrm{C}_{3}$ structure and are mainly found in glycosylated forms or esters of quinic, shikimic, and tartaric acid (Figure 1, Panel B). The most common hydroxycinnamic acids are caffeic acid, ferulic acid, $p$-coumaric acid, and sinapic acid. When combined, caffeic acid and quinic acid form chlorogenic acid, found in fruits (blueberries, kiwis, plums, cherries, apples) and in high concentrations in coffee (70-350 $\mathrm{mg}$ in a single cup) [1]. Caffeic acid, the most abundant phenolic acid, comprises $75 \%-100 \%$ of the total hydroxycinnamic acid content of most fruits. Ferulic acid is the most abundant phenolic acid in cereal grains and comprises up to $90 \%$ of the total polyphenol content of wheat grain. Dietary intake of hydroxycinnamic acids is highly variable, depending on coffee consumption [1].

\subsection{Stilbenes}

Stilbenes are phytoalexins $\left(\mathrm{C}_{6}-\mathrm{C}_{2}-\mathrm{C}_{6}\right.$ structure $)$ produced by plants as a defense against pathogens, disease, injury, and stress conditions. They have a limited presence in our diet and the main member is resveratrol (3,5,4'-trihydroxystilbene) (RES) [15] (Figure 1, Panel C). RES is present as cis and trans isomers as well as conjugated derivatives (trans-resveratrol-3-O-glucoside) in grapes, berries, plums, peanuts, and pine nuts. RES has valuable biological properties, including antioxidant, anti-inflammatory, anticancer, and antiaging activities [23-25].

\subsection{Lignans}

Lignans are plant-derived compounds whose structural similarities with estrogens classify them as phytoestrogens, similar to isoflavones [26]. They are formed by oxidation of 2 phenylpropane units and mainly occur prevalently as free form in nature. Lignans are present in high concentration in linseed and in minor concentration in algae, leguminous plants, cereals, vegetables, and fruits [1]. Lignans include ecoisolariciresinol, matairesinol, medioresinol, pinoresinol, and lariciresinol. Human gut microflora metabolize lignans into enterodiol and enterolactone [27].

\subsection{Other Polyphenols}

Among the other polyphenols, Curcumin represents the main compound. Curcumin (CUR) (1,7-bis-(4-hydroxy-3-methoxyphenyl)-1,6-heptadiene-3,5-dione), a member of the curcuminoid family, is a polyphenol compound found in turmeric, a spice produced from the rhizome of Curcuma longa [28] (Figure 1, Panel D). CUR has been studied extensively in recent years as a pleiotropic molecule able to interact with a variety of molecular targets and signal transduction pathways. It has been found to have antitumor, anti-inflammatory, antioxidant, immunomodulatory, and antimicrobial activities in both rodents and humans. CUR is considered a "multifunctional drug" due to its ability to modulate the activity of multiple targets involved in carcinogenesis through direct interaction with gene expression $[13,29]$.

\section{Polyphenols Target Signal Transduction Pathways Involved in Carcinogenesis}

As stated earlier, signal transduction pathways involved in carcinogenesis often interact with each other, enhancing oncogenic signals that trigger the malignant phenotype of cells $[3,10]$. For example, 


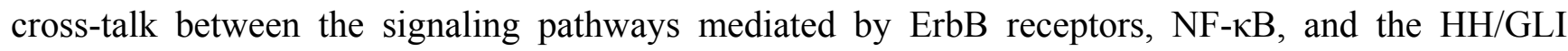
cascade plays an important role in neoplastic transformation [3].

Polyphenols can inhibit cancer cell growth by interacting with multiple signaling pathways. In this regard, different studies reported the ability of polyphenols to modulate ErbB receptors, HH/GLI and $\mathrm{NF}-\kappa \mathrm{B}$ signaling pathways in cancer cells both in vitro and in vivo.

\subsection{Modulation of ErbB Receptors Signaling Pathway by Polyphenols in Cancer Cells}

ErbB family receptors include epidermal growth factor receptor (EGFR), ErbB2 (Neu, HER2), ErbB3, and ErbB4, each of which is involved in carcinogenesis. It has been demonstrated that, after binding with specific ligands, dimerization and receptor trans-phosphorylation of ErbB receptors occur [30]. This phenomenon activates several downstream molecules that in turn activate the mitogen-activated protein kinase (MAPK) pathway, leading to increased cell proliferation and differentiation [3,31].

Polyphenols such as CUR, EGCG, RES, quercetin and apigenin have demonstrated a potent activity in affecting ErbB receptors downstream signaling in several types of cancer cells.

Squires et al. found that, in the MDA-MB-468 breast cancer cell line, CUR suppressed EGFR phosphorylation, inhibited c-fos expression and ERK activity in vitro [32]. CUR has also been shown to (a) decrease the expression of phosphorylated forms of EGFR and ERK1/2; (b) induce apoptosis and cell cycle arrest; and (c) inhibit cell proliferation in the aggressive MDA-MB-231 breast cancer cell line in vitro $[33,34]$.

It also been demonstrated that CUR induced apoptosis in several breast cancer cell lines and delayed the growth of mammary tumors in BALB-neuT transgenic mice. In vitro experiments showed that CUR inhibited the growth of breast cancer cell lines in a dose-dependent manner by enhancing the activation of apoptosis and down-regulating the activity of ERK1/2 MAPKs. In addition, the cytotoxic effects of CUR were observed in breast cancer cells expressing either high or low levels of ErbB2/neu. These results were confirmed by in vivo experiments. BALB-neuT transgenic mice were treated with CUR starting at the age at which they displayed atypical breast hyperplasia (6 weeks) or invasive breast carcinoma (16 weeks). CUR administration resulted in a significant reduction of tumor multiplicity in both early and in an advanced stage of mammary carcinogenesis, and did not modify hematological and clinical chemistry parameters in all treated mice [29].

Similar effects were also reported in gastrointestinal, prostate, pancreatic, lung, and ovarian cancer cells. Cai et al. showed that CUR demonstrated a block of proliferation and invasion of gastric cancer cells by inhibiting the expression of ErbB2 and cyclin D1 and suppressing the activity of p21-activated kinase 1 (PAK1), a downstream protein of EGFR [35].

Furthermore, in androgen responsive and refractory prostate cancer cells in vitro, CUR inhibited cell proliferation by down-regulating EGFR and ErbB2 expression [36]. CUR has also proved to be effective in inhibiting proliferation and inducing apoptosis of pancreatic and lung adenocarcinoma cells, through the modulation of cyclooxygenase-2 (COX-2), EGFR and phospho-ERK1/2 expression [37].

In HEY ovarian cancer cell line, CUR induced apoptosis in a p53-indipendent manner through the activation of p38 kinase, the down-regulation of Bcl-2 and surviving expression and the modulation of Akt signaling [38]. 
Pan et al. evaluated the ability of EGCG to counteract the growth of ErbB2- or/and ErbB3-overexpressing breast cancer cells. They reported that the anticancer activity of this polyphenol should be due to its peculiarity to interfere with heterodimerization and tyrosine phosphorylation of ErbB2-ErbB3, leading to an inhibition of the MAPK cascade pathway [39]. In an in vitro study on ErbB2/neu-overexpressing mouse mammary tumor NF639 and SMF cells, Pianetti et al. showed that EGCG decreased the phosphorylation and constitutive activation of ErbB2/neu, and suppressed the MAPK and NF- $\kappa$ B pathways, determining a sensible reduction of tumor growth [40]. Moreover, EGCG has been proved to have inhibitory properties on cell proliferation of breast and head and neck squamous cell carcinomas (HNSCC) by suppressing the activity of EGFR, signal transducer and activator of transcription 3 (STAT3), Akt and $c$-fos [41,42]. Similar effects have been observed in human colon and non-small cell lung cancer (NSCLC) cells. EGCG has demonstrated a potent ability in modulating EGFR signaling in several colon cancer cell lines [43-46]. In particular, it has been observed that EGCG was able to reduce the cellular levels of EGFR, ErbB2 and ErbB3 in the SW837 colon carcinoma cell line [43].

RES has been shown to be effective in inducing growth inhibition and apoptosis through the modulation of MAPK signaling in different cancer cell lines. In liver HepG2 cancer cell line, RES induced a suppression of cell proliferation and enhanced apoptosis by down-regulating cyclin D1, Akt, p38 kinase and Pak 1 expression, and increasing phospho-ERK1/2 protein levels [47]. Similar effects were also observed in epidermoid carcinoma and colon cancer cells [48,49].

The modulatory activity of quercetin on ErbB receptors signaling was investigated in several cancer cell lines. Jeong et al. reported that the plant polyphenol quercetin inhibited ErbB2 signaling pathway in breast cancer cells. In particular, in SKBR3 breast cancer cell line, quercetin treatment resulted in a suppression of tyrosine kinase activity and in a reduction of ErbB2/neu protein level as well as in a dephosphorylation of phosphatidylinositol-3-kinase (PI3K) and Akt [50].

Quercetin exerted its modulatory activity also on hepatoma and lung cancer cells. In the human hepatoma HepG2 cell line quercetin led to cell death by inducing suppression of Akt and ERK1/2 phosphorylation and modulating the NF- $\mathrm{B}$ pathway [51]. Similarly, in A549 lung cancer cells, quercetin induced growth inhibition and apoptosis, in a dose-dependent manner, through the inactivation of Akt-1 and the increase of ERK-MEK1/2 phosphorylation [52].

The anticancer effects of the flavonoid apigenin have been evaluated in different types of cancer cells. In PC-3 and LNCaP prostate cancer cell lines, apigenin suppressed cell proliferation, induced an arrest of the cell cycle in G0/G1 phase and reduced the phosphorylation of Rb, p38 kinase and $c$-fos protein [53]. Moreover, in breast cancer cells, at high doses, apigenin resulted in an arrest of cell growth by inhibiting the activity of several kinases involved in the downstream signaling following EGFR activation [54]. In another study performed on HNSCC cells in vitro, apigenin treatment inhibited survival and induced apotosis by reducing ligand-induced phosphorylation of EGFR and ErbB2 and modulating their downstream signaling [55].

Finally, Lee et al. evaluated the capacity of polyphenols extracted from Allium cepa Linn (PEAL) to modulate the MAPK pathway in AGS human gastric carcinoma cell line. They found that PEAL arrested tumor growth and induced apoptosis in a dose-dependent manner. This feature was associated with their ability to up-regulate p53 expression, increase Bax/Bcl-2 ratio and block Akt activity [56]. Effects of polyphenols on ErbB receptors signaling pathway in cancer cells are summarized in Table 1. 


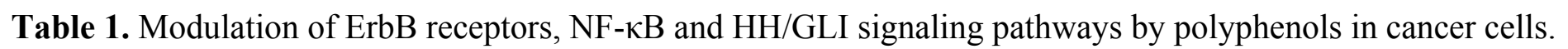

\begin{tabular}{|c|c|c|c|c|c|}
\hline $\begin{array}{l}\text { Signaling } \\
\text { Pathway }\end{array}$ & Treatment & In Vitro Model & In Vivo Model & Antitumoral Effects & Reference \\
\hline \multirow{7}{*}{$\begin{array}{l}\text { ErbB } \\
\text { receptors }\end{array}$} & \multirow{7}{*}{ CUR } & $\begin{array}{l}\text { MDA-MB-468 breast cancer cells } \\
\qquad(40 \mu \mathrm{M})\end{array}$ & & $\begin{array}{l}\downarrow \text { EGFR phosphorylation } \\
\downarrow c \text {-fos expression } \\
\downarrow \text { ERK, MKK4, JNK activity }\end{array}$ & {$[32]$} \\
\hline & & $\begin{array}{l}\text { MDA-MB-231 breast cancer cells } \\
\qquad(30-50 \mu \mathrm{M})\end{array}$ & & $\begin{array}{l}\downarrow \text { Cell proliferation } \\
\downarrow \text { EGFR, ERK } 1 / 2, \text { Akt, MAPK phosphorylation }\end{array}$ & {$[33,34]$} \\
\hline & & $\begin{array}{l}\text { Breast cancer } \\
\text { cells }(6-50 \mu \mathrm{M})\end{array}$ & $\begin{array}{l}\text { BALB-neuT transgenic mice } \\
\text { ( } 2 \mathrm{mg} \text { in } 50 \mu \mathrm{L} \text { corn oil } \\
\text { p.o. thrice weekly) }\end{array}$ & $\begin{array}{l}\downarrow \text { Tumor growth } \\
\downarrow \text { ERK } 1 / 2 \text { activity } \\
\uparrow \text { Bax } / \text { Bcl-2 ratio } \\
\uparrow \text { PARP cleavage } \\
\downarrow \text { Tumor multiplicity } \\
\downarrow\end{array}$ & [29] \\
\hline & & $\begin{array}{l}\text { Gastric cancer } \\
\text { cells }(1-100 \mu \mathrm{M})\end{array}$ & & $\begin{array}{l}\downarrow \text { Cell proliferation } \\
\downarrow \text { ErbB2, cyclin D1 expression } \\
\downarrow \text { PAK1 activity }\end{array}$ & [35] \\
\hline & & $\begin{array}{l}\text { LNCaP, C4-2B prostate cancer cells } \\
\qquad(0-100 \mu \mathrm{M})\end{array}$ & & $\begin{array}{l}\downarrow \text { Cell proliferation } \\
\downarrow \text { EGFR, ErbB2 expression }\end{array}$ & {$[36]$} \\
\hline & & $\begin{array}{l}\text { Pancreatic and lung } \\
\text { cancer cells }(0-50 \mu \mathrm{M})\end{array}$ & & $\begin{array}{l}\downarrow \text { Cell proliferation } \\
\downarrow \text { COX-2, EGFR, phospho- ERK } 1 / 2 \text { expression }\end{array}$ & [37] \\
\hline & & $\begin{array}{l}\text { HEY ovarian cancer } \\
\text { cells }(2.5-160 \mu \mathrm{M})\end{array}$ & & $\begin{array}{l}\downarrow \text { Bcl-2, Akt expression } \\
\uparrow \mathrm{p} 38 \text { activity }\end{array}$ & {$[38]$} \\
\hline
\end{tabular}


Table 1. Cont.

\begin{tabular}{|c|c|c|c|c|c|}
\hline $\begin{array}{l}\text { Signaling } \\
\text { Pathway }\end{array}$ & Treatment & In Vitro Model & In Vivo Model & Antitumoral Effects & Reference \\
\hline \multirow{12}{*}{$\begin{array}{l}\text { ErbB } \\
\text { receptors }\end{array}$} & \multirow{4}{*}{ EGCG } & $\begin{array}{l}\text { MCF-7 breast cancer cells } \\
\qquad(5-20 \mu \mathrm{M})\end{array}$ & & $\begin{array}{l}\downarrow \text { ErbB2, ErbB3 phosphorylation } \\
\downarrow \text { MAPK pathway }\end{array}$ & [39] \\
\hline & & $\begin{array}{l}\text { mammary tumor NF639 and SMF cells } \\
\qquad(0-80 \mu \mathrm{g} / \mathrm{mL})\end{array}$ & & $\begin{array}{l}\downarrow \text { Cell proliferation } \\
\downarrow \text { ErbB2/neu phosphorylation } \\
\downarrow \text { NF-kB, MAPK pathways }\end{array}$ & [40] \\
\hline & & $\begin{array}{l}\text { HNSCC }(10 \mu \mathrm{g} / \mathrm{mL}), \text { breast cancer } \\
\text { cells }(30 \mu \mathrm{g} / \mathrm{mL})\end{array}$ & & $\begin{array}{l}\downarrow \text { Cell proliferation } \\
\downarrow \text { EGFR, STAT3, Akt, c-fos activity }\end{array}$ & {$[41,42]$} \\
\hline & & $\begin{array}{l}\text { SW837 colon carcinoma cells } \\
(30 \mu \mathrm{g} / \mathrm{mL})\end{array}$ & & $\downarrow$ EGFR, ErbB2 and ErbB3 cellular levels & [43] \\
\hline & \multirow{3}{*}{ RES } & $\begin{array}{l}\text { HepG2 liver cancer } \\
\text { cells }(50-300 \mu \mathrm{M})\end{array}$ & & $\begin{array}{l}\downarrow \text { Cell proliferation } \\
\downarrow \text { Cyclin D1, Akt, p38 kinase expression } \\
\uparrow \text { Phospho-ERK1/2 protein levels } \\
\end{array}$ & [47] \\
\hline & & $\begin{array}{l}\text { A431 epidermoid carcinoma cells } \\
(0-100 \mu \mathrm{M})\end{array}$ & & $\downarrow$ Cyclin D1, MEK1, ERK1/2 expression & [48] \\
\hline & & $\begin{array}{c}\text { HT- } 29 \text { colon cancer } \\
\text { cells }(25 \mu \mathrm{M})\end{array}$ & & $\begin{array}{l}\downarrow \text { JACK-STAT pathway } \\
\downarrow \text { iNOS, COX-2 expression }\end{array}$ & [49] \\
\hline & \multirow{3}{*}{ Quercetin } & $\begin{array}{c}\text { SKBR3 breast cancer cells } \\
(100-200 \mu \mathrm{M})\end{array}$ & & $\begin{array}{l}\downarrow \text { ErbB2 tyrosin kinase activity } \\
\downarrow \text { PI3K, Akt phosphorylation }\end{array}$ & {$[50]$} \\
\hline & & $\begin{array}{c}\text { HepG2 liver cancer } \\
\text { cells }(50 \mu \mathrm{M})\end{array}$ & & $\begin{array}{l}\downarrow \text { ERK } 1 / 2, \text { Akt phosphorylation } \\
\downarrow \text { NF-kB pathway }\end{array}$ & [51] \\
\hline & & $\begin{array}{l}\text { A549 lung cancer } \\
\text { cells }(0-58 \mu \mathrm{M})\end{array}$ & & $\begin{array}{l}\downarrow \text { Cell proliferation } \\
\downarrow \text { Akt- } 1 \text { activation } \\
\uparrow \text { ERK-MEK } 1 / 2 \text { phosphorylation }\end{array}$ & {$[52]$} \\
\hline & \multirow[t]{2}{*}{ Apigenin } & $\begin{array}{l}\text { PC-3, LNCaP prostate cancer cells } \\
\qquad(5-40 \mu \mathrm{M})\end{array}$ & & $\begin{array}{l}\downarrow \text { Cell proliferation } \\
\uparrow \text { Proportion of cells in G0/G1-phase } \\
\downarrow \text { Rb, p38 kinase and } c \text {-fos phosphorylation }\end{array}$ & [53] \\
\hline & & HNSCC cells $(6-100 \mu \mathrm{M})$ & & $\begin{array}{l}\downarrow \text { Cell proliferation } \\
\downarrow \text { EGFR, ErbB2 phosphorylation }\end{array}$ & {$[55]$} \\
\hline
\end{tabular}


Table 1. Cont.

\begin{tabular}{|c|c|c|c|c|c|}
\hline $\begin{array}{l}\text { Signaling } \\
\text { Pathway }\end{array}$ & Treatment & In Vitro Model & In Vivo Model & Antitumoral Effects & Reference \\
\hline \multirow{8}{*}{$\mathrm{NF}-\kappa \mathrm{B}$} & EGCG & $\begin{array}{l}\text { A431 epidermoid carcinoma cells } \\
(10-40 \mu \mathrm{g} / \mathrm{mL})\end{array}$ & & $\begin{array}{l}\downarrow \text { Cell proliferation } \\
\downarrow N F-\kappa B / p 65 \text { nuclear translocation }\end{array}$ & [57] \\
\hline & Delphinidin & $\begin{array}{l}\text { PC-3 prostate cancer } \\
\text { cells }(30-180 \mu \mathrm{M})\end{array}$ & $\begin{array}{c}\text { Athymic }(\mathrm{nu} / \mathrm{nu}) \text { nude mice } \\
\text { bearing prostate cancer tumors } \\
(2 \mathrm{mg} \text { i.p. thrice weekly })\end{array}$ & 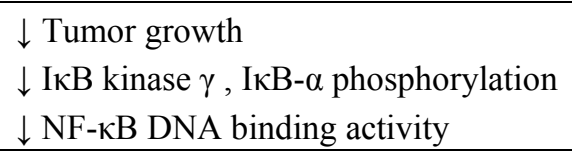 & {$[58,59]$} \\
\hline & & $\begin{array}{l}\text { HCT-116 colon cancer cells } \\
\qquad(30-240 \mu \mathrm{M})\end{array}$ & & 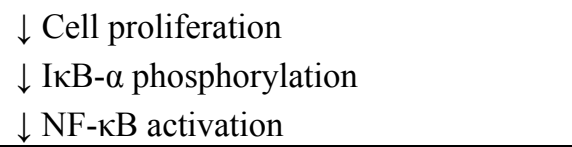 & {$[60]$} \\
\hline & & & $\begin{array}{c}\text { rats with esophagus tumor } \\
(3.8 \mu \mathrm{mol} / \mathrm{g} / \text { day p.o. })\end{array}$ & $\begin{array}{l}\downarrow \text { Tumor development } \\
\downarrow \text { NF- } \mathrm{B}, \mathrm{COX}-2 \text { expression }\end{array}$ & [61] \\
\hline & Anthocyanin & $\begin{array}{l}\text { CAL-27 oral cancer } \\
\text { cells }(0-500 \mu \mathrm{g} / \mathrm{mL})\end{array}$ & & $\begin{array}{l}\downarrow \text { Cell proliferation, metastasis } \\
\downarrow \text { NF- } \mathrm{kB}, \text { MMPs expression } \\
\downarrow \text { MAPK pathway }\end{array}$ & {$[62]$} \\
\hline & $\mathrm{CA}, \mathrm{CAPE}$ & $\begin{array}{c}\text { HepG2 liver cancer cells } \\
\text { (CA } 100 \mu \mathrm{g} / \mathrm{mL} ; \text { CAPE } 5 \mu \mathrm{g} / \mathrm{mL} \text { ) }\end{array}$ & $\begin{array}{c}\text { nude mice injected with HepG2 } \\
\text { cells (CA + CAPE } 5 \mathrm{mg} / \mathrm{kg} \mathrm{s.c} \\
\text { thrice weekly; CA + CAPE } \\
20 \mathrm{mg} / \mathrm{kg} / \text { day p.o. for } 5 \text { weeks) }\end{array}$ & $\begin{array}{l}\downarrow \text { Tumor growth } \\
\downarrow \text { NF- } \mathrm{B}, \text { MMP-9 activity } \\
\downarrow \text { Liver metastasis }\end{array}$ & [63] \\
\hline & \multirow[b]{2}{*}{ CUR } & $\begin{array}{l}\text { Cervical cancer } \\
\text { cells }(5-60 \mu \mathrm{M})\end{array}$ & & $\begin{array}{l}\downarrow \text { IאB- } \alpha \text { phosphorylation } \\
\downarrow N F-\kappa B \text { activation }\end{array}$ & [64] \\
\hline & & & ICR mice $(1-25 \mu \mathrm{M})$ & $\begin{array}{l}\downarrow \text { COX-2 expression } \\
\downarrow \text { NF- } \kappa \text { B activation } \\
\downarrow \text { NF- } \kappa B \text { nuclear translocation } \\
\downarrow \text { ERK } 1 / 2 \text { activity }\end{array}$ & [65] \\
\hline
\end{tabular}


Table 1. Cont.

\begin{tabular}{|c|c|c|c|c|}
\hline $\begin{array}{l}\text { Signaling } \\
\text { Pathway }\end{array}$ & Treatment & In Vitro Model & Antitumoral Effects & Reference \\
\hline \multirow[b]{2}{*}{$\mathrm{NF}-\kappa \mathrm{B}$} & \multirow[b]{2}{*}{ RES } & $\begin{array}{l}\text { MCF-7 breast cancer } \\
\text { cells }(50-150 \mu \mathrm{M})\end{array}$ & $\begin{array}{l}\downarrow \text { Cell proliferation } \\
\downarrow \mathrm{NF}-\kappa \mathrm{B} \text { activation } \\
\downarrow \mathrm{Bcl}-2 \text { expression }\end{array}$ & {$[66]$} \\
\hline & & $\begin{array}{l}\text { OCIM2, OCI/AML3 myeloid } \\
\text { leukemia cells }(5-75 \mu \mathrm{M})\end{array}$ & $\begin{array}{l}\downarrow \text { Cell proliferation } \\
\downarrow \text { NF- } \kappa B \text { activation } \\
\uparrow \text { PARP cleavage } \\
\uparrow \text { Proportion of cells in S-phase }\end{array}$ & {$[67]$} \\
\hline \multirow{4}{*}{ HH/GLI } & CUR & $\begin{array}{c}\text { medulloblastoma } \\
\text { cancer cells }(40 \mu \mathrm{M})\end{array}$ & $\begin{array}{l}\downarrow \text { SHH, GLI1, PTCH1 expression } \\
\uparrow \text { Proportion of cells in G2/M-phase }\end{array}$ & {$[68]$} \\
\hline & EGCG & $\begin{array}{l}\text { SW1353, CRL-7891 chondrosarcoma } \\
\text { cells }(0-4 \mu \mathrm{M})\end{array}$ & $\begin{array}{l}\downarrow \text { Cell proliferation } \\
\downarrow \text { GLI1, PTCH1 expression }\end{array}$ & {$[69]$} \\
\hline & & $\begin{array}{l}\text { pancreatic cancer stem cells } \\
\qquad(20-60 \mu \mathrm{M})\end{array}$ & $\begin{array}{l}\downarrow \text { Cell proliferation, invasion } \\
\downarrow \text { SMO, PTCH1, PTCH2, GLI1, GLI2 } \\
\text { expression }\end{array}$ & {$[70]$} \\
\hline & $\begin{array}{l}\text { Apigein, baicalein, } \\
\text { CUR, RES EGCG, } \\
\text { genistein, quercetin }\end{array}$ & $\begin{array}{l}\text { Pancreatic cancer stem cells, prostate } \\
\text { cancer cells }(20-30 \mu \mathrm{M})\end{array}$ & $\downarrow$ GLI1 expression & {$[71,72]$} \\
\hline
\end{tabular}

Abbreviations: p.o., per os; i.p., intraperitoneally; i.t., intratumorally; i.v., intravenously; s.c., subcutaneously. 


\subsection{Modulation of the NF- $\kappa B$ Pathway by Polyphenols in Cancer Cells}

Constant activation of the NF- $\kappa \mathrm{B}-$ mediated pathway is another feature of tumor cells. NF- $\mathrm{B}$ is a transcription factor retained in an active state in the cytoplasm by its inhibitors, the I $\mathrm{B}$ proteins

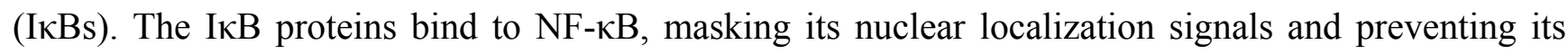
nuclear translocation [73]. Activation of the IאB kinase (IKK) complex promotes phosphorylation

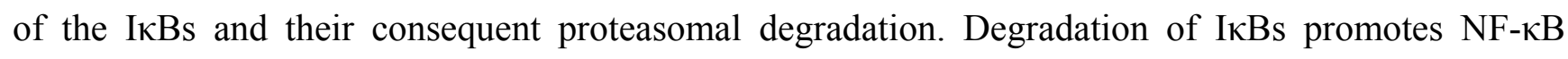
nuclear translocation. Once in the nucleus, NF- $\kappa \mathrm{B}$ activates the transcription of several genes involved in inflammation, cell growth, and invasivity [74]. Constant activation of NF- $\mathrm{kB}$ in cancer cells is linked to high production of inflammatory mediators such as tumor necrosis factor (TNF), interleukin-1 (IL-1), IL-6, prostaglandin E2 (PGE2), and reactive oxygen species (ROS) within the tumor microenvironment $[3,75,76]$. Up-regulation of $\mathrm{NF}-\mathrm{kB}$ activity is also involved in the development of chemoresistance in tumor cells, which leads to inhibition of apoptosis, increased angiogenesis, and metastatic capability [77].

Gupta et al. demonstrated that EGCG inhibited cell proliferation and induced apoptosis in a dose-dependent manner by reducing nuclear translocation of NF- $\mathrm{kB} / \mathrm{p} 65$ in human epidermoid carcinoma A431 cells [57]. Similar effects on tumor growth of different cancer cells were achieved in vitro and in vivo, using anthocyanins.

Hafeez et al. observed that delphinidin induced cell growth arrest and caspase-dependent apoptosis in a dose-dependent manner in prostate cancer cells in vitro, by reducing phosphorylation of $\mathrm{I} \kappa \mathrm{B}$

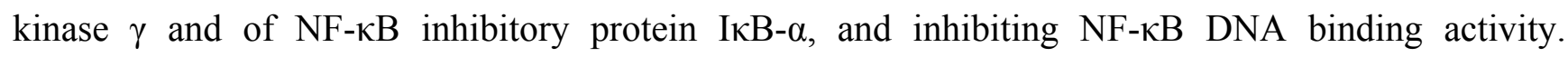
Moreover, in vivo, administration of delphinidin resulted in a significant decrease of tumor growth and $\mathrm{NF}-\kappa \mathrm{B}$ protein levels in mice bearing prostate cancer tumors [58,59].

Delphinidin exerted similar effects also in human colon cancer cells. Indeed, HCT-116 colon cancer cells treated with delphinidin showed a strong reduction of proliferation and induction of apoptosis. This phenomenon was due to the ability of this flavonoid to inhibit the activation of IKK $\alpha$ and IкB- $\alpha$ phosphorylation and the constitutive activation of NF-kB [60].

In addition, Wang et al. concluded that a diet containing anthocyanins from black raspberries inhibited the development of nitosomethylbenzylamine (NMBA)-induced rat esophagus tumors by reducing expression of NF- $\mathrm{KB}$ and COX-2 at tumor level [61].

In another study, Fan et al. observed that anthocyanins from black rice blocked oral cancer CAL-27 cells metastasis in vitro by decreasing metalloproteinases (MMPs) and NF- $\kappa$ B expression, and suppressing the MAPK pathway [62].

Caffeic acid (CA) and its derivative caffeic acid phenethyl ester (CAPE) were found to possess anticancer and antimetastatic activities on HepG2 hepatocarcinoma cells. These two compounds suppressed tumor growth both in vitro and in vivo by inhibiting NF- $\kappa \mathrm{B}$ and metalloproteinase-9 (MMP-9) activity. In addition, in vivo, the subcutaneous and oral administrations of CA and CAPE led to a significant reduction of the liver metastasis of HepG2 tumor xenografts in nude mice [63]. CUR and RES were shown to modulate the NF- $\mathrm{B}$ pathway as well.

CUR was able to induce apoptosis, suppress I $\mathrm{B}-\alpha$ phosphorylation and enhance the inhibition of $\mathrm{NF}-\kappa \mathrm{B}$ activation in cervical cancer cells [64]. 
In an in vivo study, employing a mouse skin tumor model, Chun et al. reported that CUR exerted its antitumor effects by suppression of COX-2 protein expression, activation of NF- $\kappa \mathrm{B}$ and its nuclear translocation, and inhibition of the catalytic activity of ERK1/2 in mouse skin [65].

RES has been shown to counteract tumor growth of MCF-7 breast cancer cell line in vitro, by down-regulating Bcl-2 expression and suppressing NF- $\kappa \mathrm{B}$ activity [66].

Furthermore, the inhibition of IL-1 $\beta$-induced activation of NF- $\kappa$ B by RES determined suppression of cell growth, enhancement of apoptosis and induction of cell cycle arrest in S-phase in acute myeloid leukemia cells [67].

Effects of polyphenols on the NF- $\kappa$ B signaling pathway in cancer cells are summarized in Table 1.

\subsection{Modulation of HH/GLI Pathway by Polyphenols in Cancer Cells}

The HH/GLI cascade is a complex signaling transduction pathway that controls cell proliferation, survival, and differentiation in vertebrate embryogenesis. Activation of $\mathrm{HH}$ signaling promotes translocation of the trans-membrane protein, called smoothened (SMO), in the "primary cilium", a non-motile structure protruding from the cell surface. Once SMO enters the cilium, it promotes the activation of cytoplasmic GLI proteins and their translocation to the nucleus, leading to the transcription of $\mathrm{HH}$ target gene products. Aberrant $\mathrm{HH}$ signaling has been implicated in the development and/or progression of several cancer types, including basal cell carcinoma (BCC), rhabdomyosarcoma, and gastrointestinal, lung, breast, and brain tumors [3,78-80].

Among polyphenols, CUR, EGCG and genistein exerted a potent modulatory activity on HH/GLI pathway in cancer cells. In medulloblastoma cells, CUR was able to arrest cells at the G2/M phase of the cell cycle and induce apoptosis by down-regulating the expression of the sonic hedgehog homolog (SHH) protein and its downstream molecules GLI1 and protein patched homolog 1 (PTCH1) [68]. A recent study by Tang et al. showed that EGCG affected proliferation and promoted apoptosis of SW1353 and CRL-7891 human chondrosarcoma cells in a dose-dependent manner by inhibiting PTCH1 and GLI protein expression [69].

EGCG treatment resulted in a suppression of cell proliferation and invasion of pancreatic cancer stem cells. This polyphenol exerted its anticancer activity by suppressing SMO, PTCH1, PTCH2, GLI1 and GLI2 expression [70]. In the same cells, a modulatory activity on HH/GLI pathway was also displayed by genistein [71].

Finally, Slusarz et al. reported that, when administered individually, apigein, baicalein, CUR, EGCG, genistein, quercetin, and RES inhibited the growth of prostate cancer cells in vitro and in vivo, through modulation of the HH signaling pathway [72].

Effects of polyphenols on the HH/GLI signaling pathway in cancer cells are summarized in Table 1.

\subsection{Cross-Talk between ErbB Receptors and the HH/GLI and NF- $\kappa B$ Signaling Pathways in} Cancer Cells

Cross-talk between ErbB receptors and the HH/GLI and NF- $\kappa \mathrm{B}$ signaling pathways has been shown to promote the transformation and proliferation of cancer cells. For example, the EGFR and MAPK signaling pathways promote the nuclear localization and transcriptional activity of GLI1 protein in melanoma and other cancer cells [81-85]. It was also reported that IKK $\alpha$ induces ErbB2 to 
activate NF- $\kappa \mathrm{B}$ through the canonical pathway by enhancing the invasive capacity of ErbB2 $2^{+}$breast cancer cells [86]. In addition, studies have shown that NF- $\kappa$ B promotes ErbB2-mediated tumorigenesis in vivo by enhancing tumor neo-angiogenesis, and that IKK $\alpha$ plays an important role in providing stimuli that maintain mammary tumor-initiating cells $[87,88]$. Makino et al. reported that up-regulation of IKK $\alpha$ and IKK $\beta$ by the integrin-linked kinase/Akt pathway promotes the ErbB2-mediated NF- $\mathrm{BB}$ anti-apoptotic pathway [89].

\subsection{Other Signal Transduction Pathways Involved in Carcinogenesis}

As described in the following sections, in addition to signal transduction pathways mentioned above, polyphenols are able to modulate other signals involved in carcinogenesis, such as cell cycle, apoptosis, and angiogenesis.

Two events strictly associated with carcinogenesis are the loss of function of cell cycle checkpoint genes and the inhibition of the apoptotic process.

Cell cycle checkpoints genes control cell cycle progression and ensure a high regulation of crucial events such as DNA replication and chromosome segregation. In normal cells, when damage to DNA occurs, checkpoints genes respond to damage by temporarily arresting the cell cycle by enhancing transcription of genes that facilitate repair, in order to avoid that the DNA lesion is transmitted to daughter cells during the mitosis. If the DNA damage is not repaired, cell cycle is completely arrested and the apoptotic process is activated. Loss of function of checkpoint genes results in genomic instability and has been related in the transformation of normal cells into cancer cells [9,90].

One of the most important genes involved in the regulation of the cell cycle is $\mathrm{p} 53$, because it plays a central role in eliminating the genomic damage and in inducing the apoptotic process. It is not surprising that over $70 \%$ of human cancers have mutations that lead to a loss of function of this gene or an inhibition of its downstream signal transduction pathway [91]. In addition, the frequent loss of p53 function seems to be related to the acquisition of cross-resistance to anticancer agents in human tumors [92-94].

It has been also reported that in addition to inhibiting p53 function by mutation, other p53 independent mechanisms are utilized by many cancers to alter the apoptotic process. For example, the overexpression of the anti-apoptotic bcl-2 family members (Bcl-2, Bcl-xL, MCL1, Bcl-W, A1, and Bcl-B), the suppression of activation of pro-apoptotic members (Bax, $\mathrm{BaK}$, and Bok), the aberrant expression of inhibitors of apoptosis (IAP) proteins and cellular FLICE-like inhibitory protein (C-FLIP) have been found to be related to cancer cells resistance to apoptotic stimuli and have been associated to the progression of several types of tumors [95].

Angiogenesis is a crucial process required to maintain the growth and persistence of primary tumors and to enhance the metastatic dissemination. Indeed, increased vascularization seems to be involved with the invasive properties of tumors, leading to a more aggressive malignant tumor phenotype [96].

Tumor cells induce neo-angiogenesis and enhance expression of pro-angiogenic factors such as vascular endothelial growth factor (VEGF) and fibroblast growth factors (FGF-1 and -2) [97].

PGE2 can also stimulate production of pro-angiogenic factors, activate the MAPK pathway, and increase the transcriptional activity of NF- $\mathrm{KB}[3]$. 
In summary, the capacity of polyphenols to interact with different pathways involved in carcinogenesis makes them multi-targeting agents with the potential for clinical benefit when employed in cancer treatment $[3,6,7,13,14,29,98-100]$.

\section{Bioavailability of Polyphenols}

An important topic of recent research is the analysis of the bioavailability of polyphenols. Epidemiological studies have shown an association between a diet rich in polyphenols and the prevention of human diseases. However, such beneficial effects are dependent on the proportion of active substances that are absorbed from the gastrointestinal tract [15,16]. Indeed, some of the most abundant polyphenols in our diet have little or no beneficial effect because of the low bioavailability of their bioactive metabolites [1]. In order to produce effects in vivo a compound must enter the circulation and reach the tissues, in its native or metabolized form, in a sufficient quantity to exert biological activity. Bioavailability is the quantity of a compound that is absorbed and metabolized in the human body after it is ingested, and is commonly measured in terms of maximum plasma concentration $\left(\mathrm{C}_{\max }\right)$ [4]. Polyphenols with the best bioavailability are gallic acid and isoflavones, followed by caffeic acid, flavanones, catechin, and quercetin glucosides. Anthocyanins and proanthocyanidins have the lowest bioavailability [101].

Polyphenols occur in various chemical structures that influence their intestinal absorption and the kinds of metabolites circulating in plasma [102]. In their native forms, aglycone polyphenols can be absorbed by the small intestine through passive diffusion, reaching immediately the $\mathrm{C}_{\max }$. In contrast, polyphenols in the form of esters, glycosides, or polymers undergo an intense metabolism in the small intestine before being absorbed. Glycosilated polyphenols, such as flavonols, isoflavones, flavones and anthocyanins have to be first hydrolyzed by intestinal enzymes (glucosidases and lactase-phlorizin hydrolase) or colon microflora prior to absorption. Glycosylation influences chemical and biological properties of the polyphenols, because removal of the hydrophilic moiety is usually necessary to these polyphenols to pass the intestine membrane by passive diffusion. Glycosylated polyphenols are usually absorbed more slowly than aglycone polyphenols in the intestine [1,102].

Moreover, after hydrolyzation, these polyphenols derivatives are then further metabolized in both the small intestine and the liver. They undergo a conjugation by methylation, sulfation, or glucuronidation before entering circulating plasma and target tissues. In this regard, metabolites that reach plasma are chemically different from polyphenols present in edible foods and this fact could dramatically alter their biological properties [102]. Finally, polyphenols are secreted in bile or eliminated in urine [1].

In summary, several mechanisms limit the bioavailability of polyphenols, including their metabolism in the gastrointestinal tract and liver, their binding on the surfaces of blood cells and microbial flora in the oral cavity and gut, and regulatory mechanisms that prevent the toxic effects of high flavonoid levels on mitochondria or other organelles [103].

The presence of certain types of metabolites in the plasma could depend on the interaction of polyphenols with colonic microflora. Changes in the composition of the colonic microflora could be on the basis of the inter-individual variations in bioavailability of several polyphenols. A better knowledge of the proportions of the plasma phenolic metabolites absorbed by the small intestine or by 
the colon after transformation by microflora is necessary to well elucidate mechanisms that influence the bioavailability of polyphenols [102].

In addition to endogenous factors, dietary factors can affect the bioavailability of polyphenols. A particular food matrix can affect the release of polyphenols, and food preparation techniques can alter the composition and structure of polyphenols [104]. For all these reasons, only nano- or micromolar concentrations of polyphenols and polyphenol metabolites are found in plasma $(0-4 \mu \mathrm{M}$ after an intake of $50 \mathrm{mg}$ of aglycone equivalents) [101]. Even long-term consumption of flavonoid-rich foods appears insufficient to overcome this problem [103]. Thus, the main drawbacks to the use of polyphenols as single therapy are inadequacies of absorption, biodistribution, metabolism, and bioavailability in the human body.

Compositions and methods for enhancing flavonoids bioavailability, solubility and stability in the human body have been patented, creating new flavonoids derivatives with a better biological activity and stability [4]. In addition, a promising strategy for improving the anticancer effects of polyphenols in vivo is the combined use of several polyphenols, or the combination of polyphenols and conventional cancer treatments such as chemotherapy, radiotherapy, and biopharmaceuticals.

\section{Combinations of Polyphenols: In Vitro and in Vivo Antitumoral Effects}

Several in vitro and in vivo studies have shown that treatment with polyphenols in combination is more effective in inhibiting cancer growth than treatment with a single polyphenol.

The association between pterostilbene and quercetin, two structurally related small polyphenols, has been investigated in a preclinical study, using the highly malignant B16 melanoma F10 cell line (B16M-F10). In vitro experiments showed that these two polyphenols worked synergistically to accumulate cancer cells in the G0/G1 phase and to inhibit metastasis. These findings were confirmed by in vivo experiments. Mice injected in the spleen with B16M-F10 cells, and then treated with an intravenous infusion of $20 \mathrm{mg} / \mathrm{kg} /$ day of quercetin and pterostilbene, showed a strong inhibition of the metastasis of melanoma cells to the liver and a better host survival compared to treatment with a single polyphenol [105].

Sakamoto demonstrated that the combined use of the isoflavone genistein and the polyphenol thearubigin, found in black tea, inhibited prostate cancer cell growth in vitro. Thearubigin, that alone did not inhibit growth in the human prostate tumor cell line PC-3, when combined with genistein at a 1:40 ratio, synergistically inhibited cell proliferation and induced a $\mathrm{G} 2 / \mathrm{M}$ phase cycle arrest in a dose-dependent manner [106].

In another in vivo experiment, the combination of genistein and RES acted as chemoprevention against prostate cancer in SV-40 Tag rats. Rats fed a diet with high levels of genistein and RES $(250 \mathrm{mg} / \mathrm{kg}$ ) showed an 11.5-fold decrease in prostate cancer incidence compared to controls. These effects were due to the capacity of genistein and RES to inhibit cell proliferation, decrease expression of insulin-like growth factor-1 (IGF-1) protein, and modulate sex steroid receptor and growth factor signaling in the prostate [107].

Wang et al. showed that the combination of quercetin and the flavonoid EGCG, found in green tea, decreased proliferation of human prostate cancer cells in vitro and in vivo. Quercetin enhanced the antiproliferative activity of EGCG in androgen-independent PC-3 cells and in androgen-dependent 
LNCaP prostate cancer cells in vitro by increasing the intracellular concentration of EGCG. The combined treatment caused cell cycle arrest and induced apoptosis in PC-3 cells. Quercetin also had an additive effect in LNCaP cells when administered in combination with EGCG [108].

Similarly, combined treatment with quercetin and EGCG reduced the growth of androgen-sensitive LAPC-4 prostate cancer cells more efficiently than treatment with either compound alone when injected subcutaneously in severe combined immunodeficiency (SCID) mice. Moreover, the combined treatment significantly inhibited tumor-cell proliferation, androgen-receptor expression, and PIK3/Akt signaling, and induced apoptosis in vivo. These results support the possibility to use these nontoxic compounds in combination as chemoprevention for cancer patients [109].

Another combination of polyphenols, that of EGCG and CUR, strongly suppressed the growth of NSCLC cells and breast cancer cells both in vitro and in vivo [110,111]. Zhou et al. found that, at low concentrations, the combination of EGCG and CUR synergistically enhanced cell cycle arrest of the NSCLC cell lines A549 and NCI-460 by blocking cells in the G1 and S/G2 phases. In vivo, the combination of EGCG and CUR strongly suppressed tumor growth, with no toxicity, in a lung cancer xenograft nude mouse model, suggesting that the combination of these two polyphenols may prevent NSCLC in humans [110].

Similarly, Somers-Edgar et al. demonstrated that the combination of EGCG and CUR suppressed breast cancer cell growth in vitro and in vivo. EGCG plus CUR had a synergic cytotoxic effect on the human breast cancer cell line MDA-MB-231, an effect that correlated with G2/M-phase cell cycle arrest. In addition, female athymic nude mice, implanted with MDA-MB-231 cells and treated with CUR (200 mg/kg/day) and EGCG (25 mg/kg/day) for 10 weeks, showed greater reduction of tumor volume compared to EGCG-, CUR- and vehicle control-treated mice. Moreover, this study also indicated that the combined treatment allowed for a reduced dose of CUR to achieve tumor suppression, suggesting the potential use of these two polyphenols in combination to treat breast cancer in humans [111].

Wang et al. reported that adding arctigenin (Arc), a novel anti-inflammatory lignan obtained from Arctium lappa seeds, to CUR and EGCG, synergistically increased the chemopreventive effect in the LNCaP prostate cancer cell line and the MCF-7 breast cancer cell line, compared to treatment with CUR, EGCG, or Arc alone. In particular, both Arc and EGCG enhanced CUR's ability to induce apoptosis in LNCaP cells; in MCF-7 cells, this effect was induced only by the combination of Arc and CUR. In both cell lines, the combined treatment reduced NF- $\mathrm{B}, \mathrm{PI} 3 \mathrm{~K} / \mathrm{Akt}$, and STAT3 expression and inhibited cell migration compared to any of the compounds used alone, suggesting a promising potential for the use of these three compounds in combination in clinical practice [112].

Amin et al. evaluated the anticancer effect of EGCG plus luteolin on head and neck, and lung cancer cell lines. At low doses, the combination synergistically increased apoptosis in both cell lines by activating mitochondrial-dependent and -independent processes. This combination also had an inhibiting effect on tumor growth in experiments with mice implanted with head and neck and lung cancers. In particular, a significant decrease in Ki-67 expression and an increase in $\mathrm{TUNEL}^{+}$cells were observed in tissue from xenograft models [113].

Polyphenol combinations have also shown promising effects in the treatment of leukemia. Working with MOLT-4 human leukemia cells, Mertens-Talcott et al. demonstrated that ellagic acid significantly and synergistically enhanced the ability of low-concentration quercetin to reduce cell 
proliferation, alter the cell cycle, and induce apoptosis [114]. In addition, ellagic acid and quercetin worked synergistically with RES to induce apoptosis and inhibit the growth of MOLT-4 cells. Finally, the combinations of ellagic acid plus RES and quercetin plus RES worked synergistically to induce caspase-3 activity, demonstrating again that the combination of several polyphenols has greater anticancer activity than a single polyphenol used alone [115].

The combined use of polyphenols has shown promise as a strategy against malignancies with poor prognoses, such as neuroblastoma, rhabdomyosarcoma, osteosarcoma, and head and neck carcinomas [116-119]. Liontas et al. investigated the ability of CUR and RES combined to induce apoptosis and nuclear translocation, and to activate p53 in human neuroblastoma, an aggressive childhood cancer of the peripheral nervous system that has a poor prognosis. The combination of CUR and RES decreased cell proliferation in a dose- and time-dependent manner, and induced cell cycle arrest and apotosis in several neuroblastoma cell lines in vitro. The combination also produced a transient up-regulation of p53 expression and induced nuclear translocation as well as p21 and Bax expression. The potential anticancer effect of these two polyphenols in combination may represent a new strategy for treating advanced-stage or chemo-resistant neuroblastoma [116].

The anticancer activity of the combination of diallyldisulfide (DADS), RES, and CUR has also been evaluated in malignant tumors of mesenchimal origin, such as rhabdomyosarcoma and osteosarcoma, both of which are highly aggressive pediatric malignancies with poor prognoses. The combination treatments of DADS plus RES, DADS plus CUR, and RES plus CUR were compared to treatment with single compounds. Results showed that, compared to single compounds, the combination treatments had greater in vitro anticancer activity on malignant rhabdoid (SJ-RH4, RD/18) or osteosarcoma (Saos-2) cell lines. In particular, RES and DADS potentiated the apoptotic effects of CUR on SJ-RH4 and RD/18 cell lines, suggesting that CUR-based combinations may have relevance for the treatment of p53-deficient tumor cells, which are often unaffected by conventional chemotherapies or radiotherapy [117].

RES also potentiated the in vitro and in vivo anticancer effects of CUR in HNSCC. A study reported that, compared to CUR alone, the combination of RES plus CUR increased PARP-1 cleavage, the Bax/Bcl-2 ratio, inhibition of ERK1 and ERK2 phosphorylation, and expression of the autophagic marker LC3 II in HNSCC cell lines. The model of compounds interaction indicated the onset of an additive effect of the two compounds compared to the single treatment after decrease of their concentrations. In addition, treatment with RES plus CUR reduced the growth of transplanted salivary gland cancer cells in BALB/c mice more efficiently than either CUR or RES alone [118]. Similar effects were seen in a study by Elattar et al., who found that RES combined with quercetin significantly increased inhibition of cell growth and DNA synthesis compared to quercetin alone in the SCC-25 oral squamous carcinoma cell line [119].

Finally, the combination of CUR and RES inhibited the growth of $\mathrm{p}^{+} 3^{+}$(wild type) and p53 ${ }^{-}$HCT-116 colon cancer cells in vitro and in vivo more effectively than either of the compounds used alone. Furthermore, compared to single compounds, CUR plus RES synergistically inhibited cell proliferation, stimulated apoptosis, attenuated NF- $\kappa$ B activity, and inhibited activation of EGFR and its family members. These results suggest that the combination of CUR and RES could be a promising preventive and/or therapeutic strategy for the treatment of colon cancer [120]. The effects of polyphenol combinations on cancer cells are summarized in Table 2. 
Table 2. In vitro and in vivo antitumoral effects of combinations of polyphenols.

\begin{tabular}{|c|c|c|c|c|}
\hline Treatment & In Vitro Model & In Vivo Model & Antitumoral Effects & Reference \\
\hline $\begin{array}{l}\text { Pterostilbene }+ \text { quercetin } \\
\qquad(\mathrm{s})\end{array}$ & $\begin{array}{l}\text { B16M-F10 melanoma cells ( } 40 \mu \mathrm{M} \\
\text { pterostilbene }+20 \mu \mathrm{M} \text { quercetin) }\end{array}$ & $\begin{array}{l}\text { C57BL/6J mice bearing B16M-F10 cells } \\
(20 \mathrm{mg} / \mathrm{kg} / \text { day of each polyphenol i.v.) }\end{array}$ & $\begin{array}{l}\downarrow \text { Tumor growth } \\
\downarrow \text { Metastatic activity } \\
\downarrow \text { Bcl-2 expression } \\
\uparrow \text { Mice survival } \\
\end{array}$ & {$[105]$} \\
\hline $\begin{array}{l}\text { Thearubigin }+ \\
\text { genistein (s) }\end{array}$ & $\begin{array}{c}\text { PC-3 prostate cancer cells } \\
(0.125-0.5 \mu \mathrm{g} / \mathrm{mL} \text { thearubricin }+ \\
5-20 \mu \mathrm{g} / \mathrm{mL} \text { genistein })\end{array}$ & & $\begin{array}{l}\downarrow \text { Cell proliferation } \\
\uparrow \text { Proportion of cells in G2/M-phase }\end{array}$ & {$[106]$} \\
\hline Genistein + RES & & $\begin{array}{c}\text { SV40 rats bearing prostate cancer } \\
(83-250 \mathrm{mg} / \mathrm{kg} / \text { day of each polyphenols p.o })\end{array}$ & $\begin{array}{l}\downarrow \text { Tumor growth } \\
\downarrow \text { IGF-1 expression }\end{array}$ & {$[107]$} \\
\hline Quercetin + EGCG (a) & $\begin{array}{l}\text { PC-3, LNCaP prostate cancer cells } \\
(10-20 \mu \mathrm{M} \text { of each polyphenol) }\end{array}$ & $\begin{array}{l}\text { SCID mice bearing LAPC- } 4 \text { prostate cancer cells } \\
(0.2 \%-0.4 \% \text { of each polyphenol/day p.o })\end{array}$ & $\begin{array}{l}\downarrow \text { Tumor growth } \\
\downarrow \text { AR expression } \\
\downarrow \text { PI3K/Akt pathway } \\
\uparrow \text { Bax/Bcl-2 ratio } \\
\end{array}$ & {$[108,109]$} \\
\hline \multirow{2}{*}{ CUR + EGCG (s) } & $\begin{array}{l}\text { A549, NCI-460NSCLC cells } \\
\text { (10-20 } \mu \mathrm{M} \text { of each polyphenol) }\end{array}$ & $\begin{array}{l}\text { Lung cancer xenograft node mouse model } \\
(20 \mathrm{mg} / \mathrm{kg} / \text { day of each polyphenol i.p.) }\end{array}$ & $\begin{array}{l}\downarrow \text { Tumor growth } \\
\downarrow \text { Cyclin D1 and B1 levels }\end{array}$ & {$[110]$} \\
\hline & $\begin{array}{l}\text { MDA-MB-231 breast cancer cells } \\
(2-3 \mu \mathrm{M} \text { CUR }+20-25 \mu \mathrm{M} \text { EGCG })\end{array}$ & $\begin{array}{l}\text { Athymic nude mice implanted with MDA-MB-231 cells } \\
(200 \mathrm{mg} / \mathrm{kg} / \text { day CUR p.o. }+25 \mathrm{mg} / \mathrm{kg} / \text { day EGCG i.p.) }\end{array}$ & $\begin{array}{l}\downarrow \text { Tumor volume } \\
\uparrow \text { Proportion of cells in G2/M-phase }\end{array}$ & [111] \\
\hline $\mathrm{Arc}+\mathrm{CUR}+\mathrm{EGCG}(\mathrm{s})$ & $\begin{array}{c}\text { LNCaP prostate cancer cells, MCF-7 } \\
\text { breast cancer cells }(1 \mu \mathrm{M} \text { Arc }+ \\
5-10 \mu \mathrm{M} \text { CUR }+40 \mu \mathrm{M} \mathrm{EGCG})\end{array}$ & & $\begin{array}{l}\downarrow \text { Cell proliferation } \\
\uparrow \text { Proportion of cells inG0/G1-phase } \\
\uparrow \text { Bax/Bcl-2 ratio } \\
\downarrow \text { NF- } \mathrm{B}, \text { PI3K/Akt, STAT3 } \\
\text { expression }\end{array}$ & [112] \\
\hline Luteolin + EGCG (s) & $\begin{array}{l}\text { HNSCC and lung cancer cells } \\
(10 \mu \mathrm{M} \text { luteolin }+30 \mu \mathrm{M} \text { EGCG })\end{array}$ & $\begin{array}{l}\text { Athymic nude mice implanted with HNSCC } \\
\text { and lung cancer cells }(125 \mathrm{mg} / \mathrm{kg} \text { luteolin }+10 \mathrm{mg} / \mathrm{kg} \\
\text { EGCG p.o. } 5 \text { days a week })\end{array}$ & $\begin{array}{l}\downarrow \text { Tumor growth } \\
\uparrow \text { PARP, caspase-3 cleavage } \\
\uparrow \text { p53 phosphorylation } \\
\downarrow \text { Ki-67 expression }\end{array}$ & [113] \\
\hline
\end{tabular}


Table 2. Cont.

\begin{tabular}{|c|c|c|c|c|}
\hline Treatment & In Vitro Model & In Vivo Model & Antitumoral Effects & Reference \\
\hline $\begin{array}{l}\text { Ellagic acid + quercetin; } \\
\text { Ellagic acid + RES; } \\
\text { quercetin + RES (s) }\end{array}$ & $\begin{array}{l}\text { MOLT-4 leukemia cells (ellagic acid }+ \\
\text { quercetin } 0-40 \mu \mathrm{M} \text {; Ellagic acid }+ \\
\text { RES, quercetin + RES } 0-140 \mathrm{mM} \text { ) } \\
\end{array}$ & & $\begin{array}{l}\downarrow \text { Cell proliferation } \\
\uparrow \text { Caspase-3 activity }\end{array}$ & {$[114,115]$} \\
\hline \multirow{4}{*}{ RES + CUR } & $\begin{array}{l}\text { NUB-7, LAN-5, IMR-32, SK-N-BE } \\
\text { neuroblastoma cells }(0-100 \mu \mathrm{M} \\
\text { CUR + 0-200 } \mu \mathrm{M} \text { RES })\end{array}$ & & $\begin{array}{l}\downarrow \text { Cell proliferation } \\
\uparrow \mathrm{p} 53, \text { Bax, } \mathrm{p} 21 \text { expression }\end{array}$ & [116] \\
\hline & $\begin{array}{l}\text { SJ-RH4, RD/18 rhabdomyosarcoma } \\
\text { cells, Saos-2 osteosarcoma cells } \\
(6-50 \mu \mathrm{M} \text { of each polyphenol }) \\
\end{array}$ & & $\begin{array}{l}\downarrow \text { Cell proliferation } \\
\uparrow \text { Bax/Bcl-2 ratio } \\
\downarrow \text { ERK phosphorylation }\end{array}$ & [117] \\
\hline & $\begin{array}{l}\text { CAL-27, SCC-15, FaDu, SALTO } \\
\text { HNSCCcells (6-50 } \mu \mathrm{M} \text { of each } \\
\text { polyphenol) (a) }\end{array}$ & $\begin{array}{l}\text { BALB/c mice implanted with SALTO cells ( } 2 \mathrm{mg} \text { of each } \\
\text { polyphenol in } 50 \mu \mathrm{L} \text { of corn oil p.o. thrice weekly) }\end{array}$ & $\begin{array}{l}\downarrow \text { Tumor growth } \\
\uparrow \text { PARP cleavage } \\
\uparrow \text { Bax/Bcl-2 ratio } \\
\downarrow \text { ERK1/2 phosphorylation } \\
\uparrow \text { LC3 II expression }\end{array}$ & [118] \\
\hline & $\begin{array}{l}\text { HCT-116 colon cancer cells } \\
(0-50 \mu \mathrm{M} \text { of each polyphenol) }(\mathrm{s})\end{array}$ & $\begin{array}{l}\text { SCID mice implanted with HCT-116 cells }(150 \mathrm{mg} / \mathrm{kg} / \text { day } \\
\text { RES }+500 \mathrm{mg} / \mathrm{kg} / \text { day CUR p.o. for } 3 \text { weeks })\end{array}$ & $\begin{array}{l}\downarrow \text { Tumor growth } \\
\downarrow \text { NF- } \mathrm{B}, \text { EGFR, IGF-1R activity }\end{array}$ & {$[120]$} \\
\hline
\end{tabular}

Abbreviations: (s), synergic effect; (a), additive effect; p.o., per os; i.p., intraperitoneally; i.t., intratumorally; i.v., intravenously; s.c., subcutaneously. 


\section{Combinations of Polyphenols and Anticancer Drugs: In Vitro and in Vivo Antitumoral Effects}

Conventional therapies such as chemotherapy and radiotherapy are the gold standard in cancer treatment. Unfortunately, tumor cells can become resistant to these therapies, allowing them to efflux chemotherapeutic agents, modify drug targets by altering expression of genes and proteins involved in carcinogenesis, and increase production of anti-apoptotic proteins such as Bcl-2 and Bcl-X1 [121]. Multiple factors argue for the use of natural polyphenols to enhance the anticancer effects of conventional therapies, including: their ability to modulate different signal transduction pathways involved in carcinogenesis; increasing evidence that combinations of polyphenols significantly counteract tumor growth; and the development of novel polyphenol derivatives with improved bioavailability. Combining polyphenols with conventional therapies may help to overcome drug resistance and reduce the side effects of standard anticancer treatments.

In particular, CUR has demonstrated a potent ability to increase the efficacy of conventional cancer therapies and to chemosensitize cells of colorectal, HNSCC, pancreatic, bladder, and breast tumors [122-130]. Shakibadei et al. demonstrated that CUR increased the effect of 5-fluorouracil (5-FU) against the colorectal cancer cell lines HCT116 and HCT116+ch3 (complemented with chromosome 3). Notably, pretreatment with CUR reduced $\mathrm{IC}_{50}$ values for 5-FU in both cells lines. CUR achieved this result (a) by sensitizing colon cancer cells to treatment with 5-FU, especially by augmenting the induction of apoptosis by 5-FU (favoring mitochondrial degeneration and cytochrome c release, and modulating the expression/cleavage of the pro-apoptotic proteins caspase- $8,-9,-3$, Bax, and PARP); (b) by down-regulating expression of survival proteins such as cyclin D1; and (c) by modulating NF- $\kappa \mathrm{B}$ and PI-3K/Src signaling in both cell lines. It is important to note that the best effect was achieved in HCT116+ch3 cells, suggesting that introduction of chromosome 3 played a crucial role in enhancing sensitivity of HCT116 cell line to treatment with 5-FU and/or CUR. The combination of CUR with conventional chemotherapeutic agents could be a promising strategy for increasing the efficacy of treatments for chemoresistant colon cancer cells [122].

Abuzeid et al. studied the effect of a novel CUR analog on cisplatin-sensitive (UM-SCC-74B) and cisplatin-resistant (UM-SCC-29) HNSCC cell lines in vitro. FLLL32, a novel small inhibitor derived from CUR, down-regulated the phosphorylated form of STAT3 protein and increased the number of apoptotic cells in both cell lines when used either alone or in combination with cisplatin. In particular, FLLL32 sensitized UM-SCC-29 cells to cisplatin treatment, allowing for a 4-fold reduction in the dose of cisplatin compared to the dose required for cisplatin as monotherapy [123]. CUR also potentiated the anticancer activity of gemcitabine in pancreatic cancer in vitro and in vivo in an additive manner. In vitro, CUR suppressed the growth of tumor cells, enhanced gemcitabine-induced apoptosis, and inhibited the constitutive NF-kB activation of several pancreatic cancer cell lines [124,125].

Lev-Ari et al. produced similar results in vitro by combining CUR and celecoxib. In this case, CUR synergistically potentiated the pro-apoptotic and antiproliferative effects of celecoxib in pancreatic adenocarcinoma cells [126]. In vivo, CUR enhanced the antiproliferative and antiangiogenic effects of gemcitabine in mice bearing orthotopic pancreatic tumors. Mice treated with CUR plus gemcitabine had a significant decrease in tumor volume and significant down-regulation of NF- $\mathrm{B}$-regulated genes (cyclin D1, c-myc, Bcl-2, Bcl-xL, cellular inhibitor of apoptosis protein-1, COX-2, matrix metalloproteinase, and VEGF) compared to control- and gemcitabine-treated mice [125]. In another 
study, combination treatment with CUR, raspberry extract (RSE), and neem leaf extract (NLE) effectively induced death/radiosensitization in several human pancreatic cancer cell lines. This three-compound treatment significantly reduced cell viability and increased apoptosis by: (a) enhancing the activity of caspase-3 and -7; (b) modulating the transcription of genes involved in the NF- $\kappa$ B pathway; and (c) inhibiting the NF-kB-DNA-binding activity induced by radiotherapy [127]. These results suggest the potential for these phytochemicals to enhance the effects of chemotherapy and radiotherapy, especially in the treatment of pancreatic cancer with an apoptosis-resistant phenotype [124-127].

Kamat et al. evaluated the capacity of CUR to enhance the anticancer effects of intravesical Bacillus Calmette-Guerin (BCG) in the treatment of bladder cancer. CUR potentiated the apoptotic and antiproliferative effects of BCG on different human bladder cancer cell lines in vitro by inhibiting NF- $\kappa \mathrm{B}$ activation and up-regulating TNF-related apoptosis-inducing ligand (TRAIL) receptors; these latter are proteins involved in the induction of apoptosis. CUR also potentiated the anticancer effects of BCG in syngeneic CH3 mice implanted with MBT-2 bladder cancer cells. Mice treated with CUR plus BCG showed a significant reduction of tumor growth compared to mice treated with either CUR or BCG alone. This effect was due to the ability of CUR to: (a) inhibit expression of biomarkers of proliferation (Ki-67) and angiogenesis (CD31); (b) enhance BCG-induced apoptosis; (c) reduce cyclin D1, COX-2, c-myc, Bcl-2, and VEGF expression; and (d) suppress the NF- $\mathrm{B}$ pathway in tumor tissue. These promising results suggest that CUR may improve treatments for bladder cancer [128].

CUR also has proven effects in combination with conventional therapies for breast cancer. Kang et al. investigated ability of CUR to modulate the effects of paclitaxel on breast cancer in vitro or in vivo. In the MDA-MB-231 breast cancer cell line in vitro, CUR inhibited paclitaxel-induced NF- $\kappa \mathrm{B}$ activation by blocking degradation of $\mathrm{I} \kappa \mathrm{B} \alpha$, and potentiated the antiproliferative effect of paclitaxel by enhancing induction of apoptosis. Moreover, in athymic NCr-nu/nu mice implanted with MDA-MB-231 cells, combined treatment with $100 \mathrm{mg} / \mathrm{kg}$ of CUR plus $7 \mathrm{mg} / \mathrm{kg}$ of paclitaxel (a) significantly suppressed tumor growth; (b) markedly reduced tumor cell proliferation rate; (c) improved inhibition of MMP-9 expression; and (d) enhanced apoptosis compared to treatment with CUR or paclitaxel alone. These findings suggest that CUR plus paclitaxel combination may represent a new strategy against breast cancer [129].

In another breast cancer study, Singh et al. showed that CUR and RES enhanced the susceptibility of human MCF-7 and MDA-MB-231 breast cancer cell lines to the anti-neoplastic agent Centchroman (CC). Pre-treating breast cancer cells with low-dose RES or CUR potentiated the anticancer activity of CC in both cell lines, thus increasing the number of cells in the sub-G0/G1 phase, disrupting mitochondrial membrane potential, and favoring ROS generation. RES/CUR treatment also enhanced the pro-apoptotic activity of $\mathrm{CC}$ by modulating the ROS-mediated $\mathrm{JNK} / \mathrm{p} 38$ pathway and the mitochondrial pathway in MCF-7 cells. Specifically, the combined treatment promoted phosphorylation of $\mathrm{p} 53$, alteration of the Bax/Bcl-2 ratio, and up-regulation of caspase-9 expression. Conversely, RES/CUR treatment induced only caspase-9 expression in MDA-MB-231 cells, suggesting that RES/CUR treatment could increase apoptosis without involving the ROS-mediated JNK/p38 pathway in these cells. The capacity of these two polyphenols to increase the pro-apoptotic activity of CC offers novel opportunities to design new therapies for hormone-dependent breast cancer [130].

RES has been shown to be a multi-targeting compound capable of enhancing the anticancer activity of conventional therapies for several types of cancers. Harikumar et al. reported that RES synergized the effect of gemcitabine on human pancreatic cancer cells in vitro and in vivo by: (a) inhibiting the 
NF-кB pathway; (b) inhibiting Bcl-2, Bcl-xL, COX-2, cyclin D1, MMP-9, and VEGF expression; and (c) down-regulating the production of markers for angiogenesis (CD31) and cellular proliferation (Ki-67).

In vivo, the combination of RES and gemcitabine significantly suppressed the proliferation of MIA PaCa-2 pancreatic cancer cells [131]. RES also potentiated the efficacy of the mTOR inhibitor rapamycin in several breast cancer cell lines in an additive manner, mainly by modulating the Akt signaling transduction pathway. RES inhibited the phosphorylation and activation of the PI3K/Akt pathway, enhancing the sensitivity of breast cancer cells to rapamycin in vitro [132].

RES and its metabolites have also been shown to work synergistically with chemotherapeutic agents to inhibit metastasis of human colon cancer cells. Aires et al. observed that, among various metabolites tested, RES-3-O-sulfate (R3S) most effectively inhibited growth in the human colon carcinoma cell line SW480 and its derived metastatic cell line SW620 in a time- and dose-dependent manner. Moreover, treatment with RES metabolites in combination resulted in a stronger synergic, time-, and dose-dependent anticancer effect than treatment with RES or R3S alone. RES metabolites blocked colon cancer cells in the $\mathrm{S}$ phase of the cell cycle, modulated cyclin and cyclin-dependent kinase expression, and induced apoptosis in a p53-dependent manner. Finally, RES metabolites demonstrated synergic effects with SN38 (irinotecan's active metabolites used in the treatment of metastatic colon cancer) and oxaliplatin in SW620 cells [133]. Overall these studies support the use of RES and RES metabolites as adjuvants to enhance the anticancer effects of conventional therapies [131-133].

Polyphenols present in extra virgin olive oil (EVOO) have shown strong anticancer activity that improves the efficacy of conventional treatments for several types of cancers. Menendez et al. reported that the polyphenols in EVOO can reverse acquired resistance to trastuzumab in HER2-overexpressing breast cancer cell lines. Among the polyphenols isolated in EVOO, oleuropein aglycone showed the most potent ability to inhibit breast cancer cell proliferation. SKBR3 cells, which hamper HER2 gene amplification, were about five times more sensitive to the antiproliferative activity of oleuropein aglycone than MCF-7 cells, which are HER2- In addition, when oleuropein aglycone was used in combination with trastuzumab in SKBR3 cells, it enhanced the inhibitory effects of trastuzumab in a dose-dependent manner. This effect was due to its ability to decrease the proteolytic cleavage of the HER2 extracellular domain and suppress HER2 overexpression. Oleuropein aglycone also synergistically enhanced down-regulation of HER2 expression mediated by trastuzumab and reversed acquired resistance to trastuzumab in SKBR3 cells, suggesting its potential use in the treatment of trastuzumab-resistant breast cancer [134].

Suganuma et al. conducted two studies evaluating the ability of green tea polyphenols (GTPs) to synergize with chemotherapeutic agents in the treatment of lung cancer [135,136]. The first study showed that (-) epicatechin enhanced: (a) EGCG incorporation into the human lung cancer cell line PC-9; (b) inhibition of cell growth; (c) induction of apoptosis; and (d) EGCG-mediated suppression of TNF- $\alpha$ release. In addition, the combination oftamoxifen and sulindac, which cause apoptosis in human cancer cells, and EGCG synergistically induced apoptosis in PC-9 cells in vitro [135]. The same authors also examined the effects of EGCG plus celecoxib, a COX-2 selective inhibitor, on cancer-cell proliferation. These two compounds acted synergistically to induce apoptosis by up-regulating growth arrest and expression of DNA damage-inducible gene 153 (GADD153), as well as activating the MAPK signaling pathway (phosphorylation of ERK1/2 and p38) in human lung cancer cell lines. 
These findings suggest that the selective inhibition of GADD153 expression by EGCG may be a novel strategy for improving treatments for lung cancer [136].

Similar effects on tumor growth of prostate cancer cells were achieved in vitro and in vivo, combining green tea polyphenols (GTPs) and other selective inhibitors of COX-2. EGCG worked synergistically with the COX-2 inhibitor NS398 to: (a) arrest cell growth; (b) induce apoptosis by altering the Bax/Bcl-2 ratio and increasing pro-caspase- 6 and -9 expression and PARP cleavage; (c) suppress expression of peroxisome proliferator activated receptor- $\gamma$ (PPAR- $\gamma$ ); and (d) suppress activation of NF- $\mathrm{BB}$ in multiple human prostate cancer cell lines in vitro. These results were confirmed by in vivo experiments. Androgen-sensitive human prostate carcinoma cells (CWR22Rv1) were implanted in athymic nude mice, which were then treated with GTPs $(0.1 \%$ dissolved in drinking water) and celecoxib (5 mg/kg), a COX-2 inhibitor, alone and in combination. As expected, the combined treatment resulted in a significant suppression of tumor growth compared to treatment with either agent alone. In addition, mice treated with GTPs plus celecoxib had a significant reduction in PSA and IGF-1 levels and a significant increase in serum levels of insulin-like growth factor binding protein-3 (IGFBP-3) levels compared to mice treated with either agent alone [137].

Stearns and Wang reported the additive effects of EGCG and taxanes (paclitaxel and docetaxel) in arresting the growth of human PC-3ML prostate cancer cells in vitro. EGCG plus a taxane also had an additive effect on cell death by increasing expression of the pro-apoptotic genes p53, p73, p21, and caspase-3. Moreover, combined treatment with EGCG $(228 \mathrm{mg} / \mathrm{kg})$ and paclitaxel $(20 \mathrm{mg} / \mathrm{kg})$, injected intraperitoneally, more effectively reduced tumor growth and increased survival rates in CB17 SCID mice implanted with PC-3ML cells than EGCG or paclitaxel alone. Importantly, the combination treatment also suppressed bone metastasis resulting from intravenous injection of PC-3ML cells, suggesting that EGCG may enhance the efficacy of taxanes in the treatment of advanced prostate cancer [138]. Similar results were achieved with the combination of EGCG and doxorubicin (DOX) [139].

The combination of EGCG and DOX has also proven effective in lysing synergistically liver cancer cells. Chen et al. observed that EGCG suppressed autophagic activity and blocked proliferation of hepatoma Hep3B cells in vitro and in vivo in a dose- and time-dependent manner [140]. Moreover, green tea catechins such as ECG and EGCG improved the anticancer activity of DOX in mice transplanted with human chemoresistant liver cancer cells (BEL-7404/DOX) in a dose-dependent manner. When given in combination with DOX, green tea catechins markedly reduced tumor volume, with the best effect seen at the highest dose of EGCG. Green tea catechins significantly raised intracellular accumulation of DOX in BEL-7404/DOX cells in vitro and in vivo, inhibiting the activity of the P-glycoprotein efflux pump, suggesting that catechins could be employed as adjuvants to subvert resistance to DOX in liver cancer [141].

Luo et al. demonstrated that EGCG synergistically sensitized breast cancer cell to paclitaxel in vitro and in vivo. A dramatic reduction of proliferation and an increase of taxol-induced apoptosis was observed in different breast cancer cell lines in vitro, where EGCG potentiated activation of c-Jun $N$-terminal kinases (JNKs) mediated by paclitaxel. EGCG also sensitized breast cancer cells to taxol in vivo, significantly inhibiting the growth of transplanted breast cancer cells (4T1) in BALB/c mice [142]. Remarkably, EGCG even potentiated the anticancer activity of chemotherapeutic agents in ovarian and pancreatic cancer $[143,144]$. Chan et al. reported that EGCG enhanced susceptibility to cisplatin and inhibited the growth of ovarian cancer cells through the delivery of hydrogen peroxide $\left(\mathrm{H}_{2} \mathrm{O}_{2}\right)$. 
EGCG enhanced the efficacy of cisplatin up to six-fold in the ovarian cancer cell lines SKOV3 and CAOV3, and in the C200, acisplatin-resistant cell line. EGCG also has the unusual ability to kill ovarian cancer cells by increasing levels of intracellular $\mathrm{H}_{2} \mathrm{O}_{2}$, suggesting that increasing oxidative stress may improve the efficacy of chemotherapy in ovarian cancer [143].

Tang et al. reported that EGCG potentiated the therapeutic efficacy of gemcitabine and CP690550 (tasocitinib), a STAT3 inhibitor, by modulating the STAT3 pathway in human pancreatic cancer cells. By inhibiting the STAT3-mediated pathway, EGCG blocked the migration and invasive capacity of the pancreatic cancer cell lines AsPC-1 and PANC-1 in vitro. In both cell lines, EGCG induced apoptosis by up-regulating caspase-3 activity and enhancing gemcitabine-induced cleavage of caspase-3 and PARP. The synergism of EGCG and CP690550 in inducing apoptosis suggests that EGCG may be a promising candidate for new clinical trials for the treatment of pancreatic cancer [144].

The flavonoids quercetin and genistein have also shown anticancer activity when combined with conventional therapies. Quercetin has proven very effective in enhancing the anticancer activity of chemotherapeutic agents in various types of cancers. Staedler et al. investigated the capacity of quercetin to increase the effects of DOX in human breast cancer cell lines in vitro. Quercetin potentiated the toxicity of DOX, mainly by reducing cell viability, DNA and protein synthesis, and the invasive capacity of cancer cells. These effects were more pronounced in the highly metastatic MDA-MB-231 cell line than in the less aggressive MCF-7 cell line. In addition, quercetin decreased toxic effects of DOX on non-cancer cells, suggesting a useful role in the treatment of breast cancer [145]. Quercetin has also been shown to enhance the effects of cisplatin. Kuhar et al. reported that NSCLC H-520 cells pre-treated with quercetin were more susceptible to cell killing by cisplatin than cells treated with cisplatin alone. Cells treated with quercetin plus cisplatin had an increased rate of apoptosis compared to cells treated with cisplatin alone. This effect was mediated by the ability of quercentin to suppress Bcl-xL expression and increase the Bax/Bcl-2 ratio, caspase-3 activity, and cytochrome c release in mitochondria [146]. Similar effects were reported by Sharma et al. on human laryngeal HeP2 cells, where quercetin enhanced cisplatin-mediated apoptosis in a synergic manner, modulated MAPK signaling, and induced pro-apoptotic protein expression while increasing oxidative stress and reducing HSP70 activity [147].

Different studies proved that the soy isoflavone genistein is able to potentiate the anticancer activity of cisplatin and gemcitabine. Compared to cisplatin or gemcitabine alone, the combination of genistein plus cisplatin or genistein plus gemcitabine more effectively reduced proliferation and increased apoptosis in human pancreatic carcinoma cell lines in vitro and in vivo. Genistein also suppressed cisplatin- and gemcitabine-induced activation of NF- $\mathrm{B}$ in pancreatic carcinoma-bearing mice, suggesting the potential use of this isoflavone as an adjuvant to enhance the effects of chemotherapy in pancreatic cancer [148-150]. In a prostate cancer study, Raffoul et al. found that pre-treatment with the soy isoflavones genistein, daidzein, and glycitein enhanced cell killing by radiation of PC-3 cells in vitro. The soy isoflavones achieved this result by activating apoptosis through up-regulation of Bax expression and PARP cleavage and down-regulation of $\mathrm{Bcl}-\mathrm{xL}$ and survivin expression. In vivo, treatment with soy isoflavones potentiated the inhibition of tumor growth by radiation and stabilized metastasis to para-aortic lymph nodes in a PC-3 orthotopic metastatic mouse model, suggesting a potential role for these compounds in new treatments for prostate cancer [151]. The anticancer effects of polyphenols in combination with anticancer agents are summarized in Table 3. 
Table 3. In vitro and in vivo antitumoral effects of polyphenols in combination with anticancer drugs.

\begin{tabular}{|c|c|c|c|c|}
\hline Treatment & In Vitro Model & In Vivo Model & Antitumoral Effects & Reference \\
\hline $\mathrm{CUR}+5-\mathrm{FU}$ & $\begin{array}{l}\text { HCT-116 colon cancer cells } \\
(5 \mu \mathrm{M} \text { CUR }+0-5 \mu \mathrm{M} 5-\mathrm{FU})\end{array}$ & & $\begin{array}{l}\downarrow \mathrm{IC}_{50} \text { of 5-FU } \\
\uparrow \text { Cytocrome c release } \\
\uparrow \text { PARP, caspase-3,-8,-9 cleavage } \\
\downarrow \text { Cyclin D1 expression } \\
\downarrow \text { NF- } \kappa \mathrm{B}, \mathrm{PI}-3 \mathrm{~K} / \mathrm{Src} \text { activity }\end{array}$ & [122] \\
\hline CUR + cisplatin & $\begin{array}{c}\text { UM-SCC-74B, UM-SCC-29 HNSCC } \\
\text { cells }(0.3-5 \mu \mathrm{M} \text { CUR }+ \\
3-50 \mu \mathrm{M} \text { cisplatin }) \\
\end{array}$ & & $\begin{array}{l}\downarrow \text { Cell proliferation } \\
\downarrow \text { STAT3 phosphorylation }\end{array}$ & {$[123]$} \\
\hline \multirow[b]{2}{*}{ CUR + gemcitabine (a) } & $\begin{array}{c}\text { P34, Panc-1 pancreatic cancer cells. } \\
(10-15 \mu \mathrm{M} \text { CUR }+ \\
0.1-0.5 \mu \mathrm{M} \text { gemcitabine }) \\
\end{array}$ & & $\begin{array}{l}\downarrow \text { Cell proliferation } \\
\downarrow \text { COX-2 and p-ERK1/2expression }\end{array}$ & {$[124]$} \\
\hline & $\begin{array}{l}\text { BxPC-3, MIA PaCa-2, Panc-1 } \\
\text { pancreatic cancer cells (10 } \mu \mathrm{M} \text { CUR } \\
\quad+50 \mathrm{nM} \text { gemcitabine })\end{array}$ & $\begin{array}{l}\text { Mice bearing pancreatic tumors } \\
(1 \mathrm{~g} / \mathrm{kg} / \text { day CUR p.o. }+25 \mathrm{mg} / \mathrm{kg} \\
\text { gemcitabine i.p. twice weekly) }\end{array}$ & $\begin{array}{l}\downarrow \text { Tumor growth } \\
\downarrow \text { NF- } \kappa \text { B activity } \\
\downarrow \text { Cyclin D1, c-myc, Bcl-2,Bcl-xL, COX-2, MMP, } \\
\text { VEGF expression }\end{array}$ & {$[125]$} \\
\hline CUR + celecoxib (s) & $\begin{array}{c}\text { P-34, MIA PaCa, Panc-1 } \\
\text { pancreatic cancer cells (15 } \mu \mathrm{M} \text { CUR } \\
+25 \mu \mathrm{M} \text { celecoxib) }\end{array}$ & & $\begin{array}{l}\downarrow \text { Cell proliferation } \\
\downarrow \text { COX-2 expression }\end{array}$ & {$[126]$} \\
\hline $\begin{array}{c}\text { CUR }+ \text { RSE + } \\
\text { NLE + radiotherapy }\end{array}$ & $\begin{array}{c}\text { BxPC-3, MIA PaCa-2, Panc-1 } \\
\text { pancreatic cancer cells (100 nM CUR } \\
+1 \mu \mathrm{g} \text { RSE }+0.01 \% \mathrm{NLE}+ \\
10 \text { Gy radiotherapy) }\end{array}$ & & $\begin{array}{l}\downarrow \text { Cell proliferation } \\
\uparrow \text { Caspase- } 3,-7 \text { activity } \\
\downarrow \text { NF- } \kappa \text { B activity }\end{array}$ & {$[127]$} \\
\hline CUR + BCG & $\begin{array}{l}\text { MBT-2, 253J-BV, KU-7, RT4V6 } \\
\text { bladder cancer cells }(0-25 \mu \mathrm{M} \text { CUR } \\
\left.+10^{6} \text { CFU BCG }\right)\end{array}$ & $\begin{array}{l}\text { Syngeneic mice implanted with MBT-2 } \\
\text { cells ( } 1 \mathrm{~g} / \mathrm{kg} / \text { day CUR p.o. }+10^{6} \mathrm{CFU} \\
\text { BCG i.t. once weekly) }\end{array}$ & 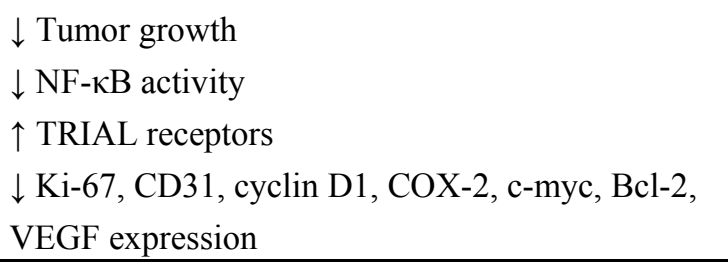 & {$[128]$} \\
\hline
\end{tabular}


Table 3. Cont.

\begin{tabular}{|c|c|c|c|c|}
\hline Treatment & In Vitro Model & In Vivo Model & Antitumoral Effects & Reference \\
\hline CUR + paclitaxel & $\begin{array}{c}\text { MDA-MB-231breast } \\
\text { cancer cells }(0.01-10 \mu \mathrm{M} \text { CUR }+ \\
0.2-100 \mu \mathrm{M} \text { paclitaxel })\end{array}$ & $\begin{array}{l}\text { Athymic nude mice implanted with } \\
\text { MDA-MB-231 cells }(100 \mathrm{mg} / \mathrm{kg} / \text { day } \\
\text { CUR p.o. }+7 \mathrm{mg} / \mathrm{kg} \text { paclitaxel } \\
\text { i.p. weekly) }\end{array}$ & 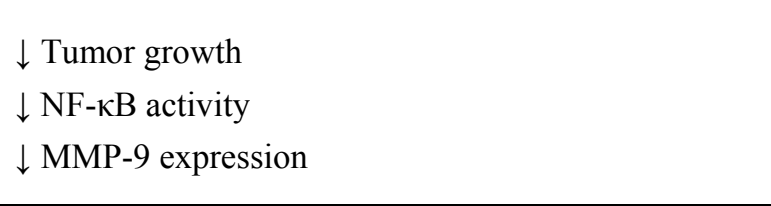 & [129] \\
\hline $\mathrm{RES}+\mathrm{CUR}+\mathrm{CC}$ & $\begin{array}{c}\text { MCF-7, MDA-MB-231 breast cancer } \\
\text { cells }(10-100 \mu \mathrm{M} \text { RES }+ \\
10-30 \mu \mathrm{M} \text { CUR }+10 \mu \mathrm{M} \mathrm{CC})\end{array}$ & & $\begin{array}{l}\uparrow \text { Proportion of cells in G0/G1-phase } \\
\uparrow \text { ROS generation } \\
\uparrow \text { p53 phosphorylation } \\
\uparrow \mathrm{Bax} / \mathrm{Bcl}-2 \text { ratio } \\
\uparrow \text { Caspase- } 9 \text { expression }\end{array}$ & {$[130]$} \\
\hline RES + gemcitabine (s) & $\begin{array}{c}\text { ASPC-1, MIA PaCa-2, Panc-1 } \\
\text { pancreatic cancer cells } \\
(10 \mu \mathrm{M} \text { RES + } 100 \mathrm{nM} \text { gemcitabine })\end{array}$ & $\begin{array}{l}\text { Athymic nude mice implanted with } \\
\text { MIA PaCa- } 2 \text { cells ( } 40 \mathrm{mg} / \mathrm{kg} / \text { day } \\
\text { RES p.o. }+25 \mathrm{mg} / \mathrm{kg} \text { gemcitabine i.p. } \\
\text { twice weekly) }\end{array}$ & $\begin{array}{l}\downarrow \text { Tumor growth } \\
\downarrow \text { NF- } \kappa \text { B activity } \\
\downarrow \text { Cyclin D1, Bcl-2, Bcl-xL, COX-2, MMP-9, VEGF, } \\
\text { Ki-67, CD31 expression }\end{array}$ & {$[131]$} \\
\hline RES + rapamycin (a) & $\begin{array}{l}\text { MCF-7, MDA-MB-231, BT-549 } \\
\text { breast cancer cells (10-50 } \mu \text { M RES + } \\
0-10,000 \mathrm{nM} \text { rapamycin })\end{array}$ & & $\begin{array}{l}\downarrow \text { Cell proliferation } \\
\downarrow \text { PI3K/Akt pathway }\end{array}$ & [132] \\
\hline $\begin{array}{l}\text { RES metabolites }+ \text { SN38 } \\
\quad \text { or oxaliplatin }(\mathrm{s})\end{array}$ & $\begin{array}{c}\text { SW480, SW620 colon cancercells } \\
(0-60 \mu \mathrm{M} \text { RES }+50 \mathrm{nM} \text { SN38 or } \\
500 \mathrm{nM} \text { oxaliplatin })\end{array}$ & & $\begin{array}{l}\downarrow \text { Cell proliferation } \\
\uparrow \text { Proportion of cells in S-phase } \\
\uparrow \text { p53 phosphorylation }\end{array}$ & [133] \\
\hline $\mathrm{EVOO}+$ trastuzumab $(\mathrm{s})$ & $\begin{array}{c}\text { MCF-7, SKBR3 breast cancer } \\
\text { cells }(50 \mu \mathrm{M} \text { EVOO }+ \\
100 \mu \mathrm{g} / \mathrm{mL} \text { trastuzumab) }\end{array}$ & & $\begin{array}{l}\downarrow \text { Cell proliferation } \\
\downarrow \text { HER-2 expression }\end{array}$ & {$[134]$} \\
\hline $\begin{array}{c}\text { EGCG + tamoxifen or } \\
\text { sulindac }(\mathrm{s})\end{array}$ & $\begin{array}{l}\text { PC-9 lung cancer cells }(75 \mu \mathrm{M} \\
\text { EGCG }+0-20 \mu \mathrm{M} \text { tamoxifen or } \\
0-200 \mu \mathrm{M} \text { sulindac })\end{array}$ & & $\begin{array}{l}\downarrow \text { Cell proliferation } \\
\downarrow \text { TNF- } \alpha \text { release }\end{array}$ & {$[135]$} \\
\hline
\end{tabular}


Table 3. Cont.

\begin{tabular}{|c|c|c|c|c|}
\hline Treatment & In Vitro Model & In Vivo Model & Antitumoral Effects & Reference \\
\hline EGCG+ celecoxib $(s)$ & $\begin{array}{c}\text { PC-9, A549, ChaGo K-1 lung } \\
\text { cancer cells (100 } \mu \mathrm{M} \text { EGCG }+ \\
1-50 \mu \mathrm{M} \text { celecoxib) }\end{array}$ & & $\begin{array}{l}\downarrow \text { Cell proliferation } \\
\uparrow \text { GADD153 expression } \\
\uparrow \text { ERK1/2, p38 phosphorylation }\end{array}$ & {$[136]$} \\
\hline $\begin{array}{c}\mathrm{EGCG}+\mathrm{NS} 38 \text { or } \\
\text { celecoxib (s) }\end{array}$ & $\begin{array}{c}\text { LNCaP, PC-3, CWR22Rv1 } \\
\text { prostate cancer cells (10-40 } \mu \mathrm{M} \\
\text { EGCG }+10 \mu \mathrm{MNS} 38)\end{array}$ & $\begin{array}{l}\text { Athymic nude mice implanted with } \\
\text { CWR22Rv1 cells }(0.1 \% \text { EGCG in } \\
\text { drinking water/day }+5 \mathrm{mg} / \mathrm{kg} / \text { day } \\
\text { celecoxib i.p. } 5 \text { days per week) }\end{array}$ & $\begin{array}{l}\downarrow \text { Tumor growth } \\
\uparrow \text { Bax/Bcl-2 ratio } \\
\uparrow \text { PARP cleavage } \\
\uparrow \text { Caspase- } 3,-9 \text { expression } \\
\downarrow \text { NF- } \kappa \text { B activity } \\
\downarrow \text { PPAR- } \gamma \text { expression } \\
\downarrow \text { PSA, IGF- } 1 \text { serum levels }\end{array}$ & {$[137]$} \\
\hline $\begin{array}{c}\text { EGCG }+ \text { paclitaxel or } \\
\text { docetaxel (a) }\end{array}$ & $\begin{array}{c}\text { PC-3ML prostate cancer cells } \\
(30 \mu \mathrm{M} \text { EGCG }+6.25 \mathrm{nM} \text { paclitaxel } \\
\text { or } 3.12 \mathrm{nM} \text { docetaxel })\end{array}$ & $\begin{array}{c}\text { CB17 SCID mice implanted with } \\
\text { PC-3ML cells ( } 228 \mathrm{mg} / \mathrm{kg} / \text { day EGCG + } \\
20 \mathrm{mg} / \mathrm{kg} \text { paclitaxel i.p.weekly) }\end{array}$ & $\begin{array}{l}\downarrow \text { Tumor growth } \\
\uparrow \mathrm{p} 53, \mathrm{p} 73, \mathrm{p} 21 \text {, caspase-3 expression } \\
\uparrow \text { Mice survival rate } \\
\downarrow \text { Bone metastasis }\end{array}$ & [138] \\
\hline $\mathrm{EGCG}+\mathrm{DOX}$ & $\begin{array}{c}\text { IBC-10a, PCa- } 20 \mathrm{a}, \mathrm{PC}-3 \mathrm{ML} \\
\text { prostate cancer cells }(0-60 \mu \mathrm{M} \\
\text { EGCG }+2 \mathrm{nM} \text { or } 1-6 \mu \mathrm{M} \text { DOX })\end{array}$ & $\begin{array}{c}\text { NOD-SCID mice implanted } \\
\text { with PC-3ML cells }(200 \mu \mathrm{M} \text { EGCG }+ \\
2 \mu \mathrm{M} \text { DOX })\end{array}$ & $\begin{array}{l}\downarrow \text { Tumor growth } \\
\uparrow \text { PARP cleavage } \\
\uparrow \text { Mice survival rate } \\
\end{array}$ & [139] \\
\hline $\mathrm{ECG}+\mathrm{EGCG}+\mathrm{DOX}$ & $\begin{array}{c}\text { BEL-7404/DOX liver cancer cells } \\
(60 \mathrm{mg} / \mathrm{mL} \text { ECG or } 14 \mathrm{mg} / \mathrm{mL} \\
\text { EGCG }+0.8-2.0 \mathrm{mg} / \mathrm{mL} \text { DOX })\end{array}$ & $\begin{array}{c}\text { BALB/c nu/nu mice implanted with } \\
\text { BEL-7404/DOX cells } \\
(40-160 \mathrm{mg} / \mathrm{kg} \text { EGCG }+ \\
2 \mathrm{mg} / \mathrm{kg} \text { DOX i.p. })\end{array}$ & $\begin{array}{l}\downarrow \text { Tumor growth } \\
\downarrow \mathrm{IC}_{50} \text { of DOX } \\
\downarrow \text { P-glycoprotein expression }\end{array}$ & [141] \\
\hline EGCG + paclitaxel (s) & $\begin{array}{l}\text { 4T1, MCF-7, MDA-MB-231 } \\
\text { breast cancer cells }(20 \mu \mathrm{M} \text { EGCG }+ \\
2 \mu \mathrm{M} \text { paclitaxel })\end{array}$ & $\begin{array}{c}\text { BALB/c mice implanted with } \\
4 \mathrm{~T} 1 \mathrm{cells}(30 \mathrm{mg} / \mathrm{kg} / \text { day EGCG i.p. }+ \\
10 \mathrm{mg} / \mathrm{kg} \text { paclitaxel i.p. thrice weekly) }\end{array}$ & $\begin{array}{l}\downarrow \text { Tumor growth } \\
\uparrow \text { JNK phosphorylation }\end{array}$ & {$[142]$} \\
\hline EGCG + cisplatin & $\begin{array}{l}\text { SKOV3, CAOV3, C200 ovarian } \\
\text { cancer cells }(0-20 \mu \mathrm{M} \text { EGCG }+ \\
1-350 \mu \mathrm{g} / \mathrm{mL} \text { cisplatin })\end{array}$ & & $\begin{array}{l}\downarrow \text { Cell proliferation } \\
\uparrow \mathrm{H}_{2} \mathrm{O}_{2} \text { levels }\end{array}$ & {$[143]$} \\
\hline
\end{tabular}


Table 3. Cont

\begin{tabular}{|c|c|c|c|c|}
\hline Treatment & In Vitro Model & In Vivo Model & Antitumoral Effects & Reference \\
\hline $\begin{array}{l}\text { EGCG }+ \text { gemcitabine or } \\
\text { tasocitinib (s) }\end{array}$ & $\begin{array}{c}\text { AsPC-1, PANC-1 pancreatic cancer } \\
\text { cells }(0-60 \mu \mathrm{M} \text { EGCG }+0.5 \mu \mathrm{M} \\
\text { gemcitabine or tasocitinib) }\end{array}$ & & $\begin{array}{l}\downarrow \text { Cell proliferation } \\
\downarrow \text { STAT3 pathway } \\
\downarrow \text { Cell migration } \\
\uparrow \text { PARP and caspase-3 cleavage }\end{array}$ & {$[144]$} \\
\hline Quercetin + DOX & $\begin{array}{c}\text { MCF-7, MDA-231 breast } \\
\text { cancer cells }(5-10 \mu \mathrm{M} \text { quercetin }+ \\
10-100 \mathrm{nM} \text { DOX })\end{array}$ & & $\begin{array}{l}\downarrow \text { Cell proliferation } \\
\downarrow \text { DNA and protein synthesis } \\
\downarrow \text { Cell invasivity }\end{array}$ & {$[145]$} \\
\hline & $\begin{array}{l}\text { H520 NSCLC cells ( } 40 \mu \mathrm{M} \text { quercetin } \\
+5 \mu \mathrm{g} / \mathrm{mL} \text { cisplatin })\end{array}$ & & $\begin{array}{l}\uparrow \text { Apoptotic rate } \\
\uparrow \text { Bax/Bcl-2 ratio } \\
\uparrow \text { Caspase-3 activity } \\
\uparrow \text { Cytochrome c release } \\
\downarrow \text { Bcl-xL expression }\end{array}$ & [146] \\
\hline Quercetin + cisplatin & $\begin{array}{l}\text { HeP2 laryngeal cancer cells ( } 40 \mu \mathrm{M} \\
\text { quercetin }+2.5 \mu \mathrm{g} / \mathrm{mL} \text { cisplatin) (s) }\end{array}$ & & $\begin{array}{l}\downarrow \text { Akt phosphorylation } \\
\uparrow \mathrm{JNK} \text { phosphorylation } \\
\uparrow c \text {-fos expression } \\
\uparrow \mathrm{Bax} / \mathrm{Bcl}-2 \text { ratio } \\
\downarrow \text { Bcl-xL, Ki-67 expression } \\
\uparrow \text { Cytochrome c release } \\
\uparrow \text { Caspase- } 8,-9 \text { activity } \\
\uparrow \text { ROS production } \\
\downarrow \text { HSP70 activity }\end{array}$ & [147] \\
\hline
\end{tabular}


Table 3. Cont

\begin{tabular}{|c|c|c|c|c|}
\hline Treatment & In Vitro Model & In Vivo Model & Antitumoral Effects & Reference \\
\hline & $\begin{array}{c}\text { BxPC-3 pancreatic cancer cells } \\
(25 \mu \mathrm{M} \text { genistein }+ \\
0.5 \mu \mathrm{M} \text { cisplatin }) \\
\end{array}$ & $\begin{array}{l}\text { SCID mice implanted with BxPC-3 } \\
\text { cells }(800 \mu \mathrm{g} / \mathrm{kg} / \text { day genistein p.o. }+ \\
\quad 9 \mathrm{mg} / \mathrm{kg} \text { cisplatin/day i.p.) }\end{array}$ & $\begin{array}{l}\downarrow \text { Tumor growth } \\
\downarrow \text { NF- } \kappa \text { B activity }\end{array}$ & {$[148]$} \\
\hline Genistein + cisplatin & $\begin{array}{l}\text { Panc-28, COLO-357, L3.6pl } \\
\text { pancreatic cancer cells ( } 30 \mu \mathrm{M} \\
\text { genistein }+1-2 \mu \mathrm{M} \text { cisplatin })\end{array}$ & $\begin{array}{l}\text { SCID mice implanted with } \\
\text { COLO-357 cells }(1 \mathrm{mg} / \text { day genistein p.o. } \\
\quad+9 \mathrm{mg} / \mathrm{kg} \text { cisplatin i.p. })\end{array}$ & $\begin{array}{l}\downarrow \text { Tumor growth } \\
\downarrow \text { NF- } \kappa \text { B activity } \\
\downarrow \text { Bcl-2, Bcl-xL, MMP-9 expression } \\
\uparrow \text { PARP and caspase-3 cleavage } \\
\downarrow \text { Akt phosphorylation } \\
\uparrow \text { Cytochrome c release }\end{array}$ & [149] \\
\hline Genistein + gemcitabine & $\begin{array}{c}\text { COLO-357, L3.6pl pancreatic cancer } \\
\text { cells ( } 25 \mu \mathrm{M} \text { genistein }+ \\
25 \mathrm{nM} \text { gemcitabine })\end{array}$ & $\begin{array}{l}\text { SCID mice implanted with } \\
\text { COLO-357 and L3.6pl cells } \\
(1 \mathrm{mg} / \text { day genistein p.o. }+ \\
80 \mathrm{mg} / \mathrm{kg} / \text { day gemcitabine i.v. })\end{array}$ & $\begin{array}{l}\downarrow \text { Tumor growth } \\
\downarrow \text { NF- } \kappa \text { B activity } \\
\uparrow \text { PARP and caspase-3 cleavage } \\
\uparrow \text { Cytochrome c release } \\
\downarrow \text { Bcl- } 2, \text { Bcl-xL expression } \\
\downarrow \text { Akt phosphorylation }\end{array}$ & {$[150]$} \\
\hline $\begin{array}{l}\text { Isoflavones }+ \\
\text { radiotherapy }\end{array}$ & $\begin{array}{l}\text { PC-3 prostate cancer cells ( } 0-15 \mu \mathrm{M} \\
\text { isoflavones }+3 \text { Gy radiotherapy) }\end{array}$ & $\begin{array}{l}\text { Nude mice implanted with PC-3 cells (1 } \\
\text { mg/day isoflavones p.o. }+ \\
5 \text { Gy radiotherapy) }\end{array}$ & $\begin{array}{l}\downarrow \text { Tumor growth } \\
\uparrow \text { Bax expression } \\
\uparrow \text { PARP cleavage } \\
\downarrow \text { Bcl-xL, survivin expression } \\
\downarrow \text { Metastasis to para-aorticlymph nodes }\end{array}$ & {$[151]$} \\
\hline Cur-NPs & $\begin{array}{c}\text { CAL-27-cisplatin-resistent HNSCC } \\
\text { cells }(0-80 \mu \mathrm{M})\end{array}$ & & $\begin{array}{l}\downarrow \text { Cell proliferation } \\
\uparrow \text { Bax expression } \\
\uparrow \text { Caspase- } 3,-9 \text { synthesis } \\
\downarrow \text { Bcl-2, MDR } 1 \text { expression } \\
\uparrow \text { ROS production }\end{array}$ & {$[152]$} \\
\hline
\end{tabular}


Table 3. Cont.

\begin{tabular}{|c|c|c|c|c|}
\hline Treatment & In Vitro Model & In Vivo Model & Antitumoral Effects & Reference \\
\hline GLUT1-PEG-PE & HCT -116 colon cancer cells & NU/NU nude mice implanted & $\downarrow$ Cell viability & \\
\hline micelles co-loaded with & (7.5-20 $\mu \mathrm{M}$ CUR + & with HCT-116 cells ( $4 \mathrm{mg} / \mathrm{kg} /$ day CUR & $\downarrow$ Tumor growth & {$[153]$} \\
\hline CUR and DOX & $0.1-0.4 \mu \mathrm{M}$ DOX) & + $0.4 \mathrm{mg} / \mathrm{kg} /$ day DOX i.v.) & $\uparrow$ Mice survival & \\
\hline $\begin{array}{c}\text { MPEG-PCL } \\
\text { micelles loaded with CUR } \\
\text { and DOX (s) }\end{array}$ & $\begin{array}{l}\text { LL/2, MS1 lung cancer cells } \\
(0-3 \mu \mathrm{g} / \mathrm{mL} \text { CUR and DOX) }\end{array}$ & $\begin{array}{l}\text { C57 mice implanted with LL/2 cells } \\
(5 \mathrm{mg} / \mathrm{kg} \text { CUR }+5 \mathrm{mg} / \mathrm{kg} \text { DOX i.v. } \\
\text { every five days })\end{array}$ & $\begin{array}{l}\downarrow \text { Tumor growth } \\
\uparrow \text { Apoptosis } \\
\downarrow \text { Angiogenesis }\end{array}$ & {$[154]$} \\
\hline $\begin{array}{c}\text { Liposomal } \\
\text { CUR + cisplatin }\end{array}$ & $\begin{array}{c}\text { CAL-27, UM-SCC1 HNSCC } \\
\text { cells }(100 \mu \mathrm{M} \text { CUR }+ \\
10-20 \mu \mathrm{M} \text { cisplatin })\end{array}$ & $\begin{array}{c}\text { Athymic nude mice implanted with } \\
\text { HNSCC cells }(50 \mathrm{mg} / \mathrm{kg} \text { CUR i.v. } \\
\text { thrice weekly for three weeks }+ \\
0.75 \mu \mathrm{g} / \mathrm{mL} \text { cisplatin i.p. after } 4 \text { weeks) }\end{array}$ & 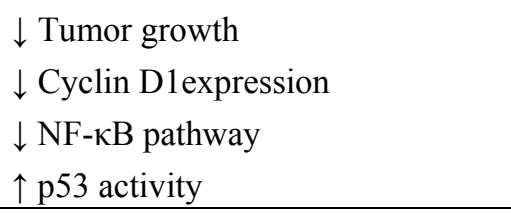 & {$[155]$} \\
\hline $\begin{array}{l}\text { PLGA-Nano-CUR } \\
\text { particles + cisplatin or } \\
\text { radiotherapy }\end{array}$ & $\begin{array}{c}\text { cisplatin-resistant A2780CP } \\
\text { ovarian cancer cells }(2-20 \mu \mathrm{M} \text { CUR } \\
+2.5-40 \mu \mathrm{M} \text { cisplatin; } 2-8 \mu \mathrm{M} \text { CUR } \\
+0-4 \text { Gy radiotherapy) }\end{array}$ & & $\begin{array}{l}\downarrow \text { Cell proliferation } \\
\downarrow \text { Bcl-xL, Mcl-1 expression } \\
\uparrow \text { PARP, caspase-3, -7, -9 cleavage } \\
\downarrow \beta \text {-Catenin activity }\end{array}$ & {$[156]$} \\
\hline
\end{tabular}

Abbreviations: (s), synergic effect; (a), additive effect; p.o., per os; i.p., intraperitoneally; i.t., intratumorally; i.v., intravenously; s.c., subcutaneously. 


\section{Combinations of Polyphenols in Clinical Trials}

Promising preclinical data on the use of combinations of polyphenols or polyphenols and anticancer drugs have spurred interest in using these natural compounds in the clinical setting. Several ongoing and completed clinical trials have reported the safety and efficacy of polyphenols as anticancer agents [157-160]. However, few clinical trials have evaluated polyphenols in combination with conventional cancer treatments. In a phase I dose-escalation trial combining CUR and docetaxel in advanced and metastatic breast cancer, Bayet-Robert et al. demonstrated that the best-tolerated dose of CUR was $6000 \mathrm{mg}$ /day given orally for seven days every three weeks in combination with a standard dose $\left(100 \mathrm{mg} / \mathrm{m}^{2}\right)$ of docetaxel given every three weeks for six cycles. This therapeutic protocol proved more effective than treatment with docetaxel alone in reducing tumor marker levels and tumor burden. In addition, concurrent administration of CUR did not increase the side effects of docetaxel, demonstrating the feasibility, safety, and tolerability of this combined treatment. A phase II randomized clinical trial is ongoing to elucidate the mechanism of action by which CUR enhances the efficacy of docetaxel in the treatment of advanced and metastatic breast cancer [161].

Another clinical trial is evaluating the anticancer effects of EGCG in breast cancer patients receiving radiotherapy. Data from this ongoing trial reveal that EGCG in capsule (400 $\mathrm{mg}$ three times a day) reduced serum VEGF and HGF levels and suppressed MMP-9/MMP-2 activation, factors associated with the progression and metastasis of breast cancer. When added to a culture medium containing highly aggressive human MDA-MD-231 breast cancer cells, sera from patients treated with EGCG plus radiotherapy strongly suppressed cell viability, arrested the cell cycle at the G0/G1 phase, and induced apoptosis [162].

\section{Nanotechnology and Polyphenols}

There have been few clinical trials of polyphenols in combination with conventional cancer therapies, possibly because the metabolism, stability, drug interactions, side effects, and mechanisms of action of these plant derivatives have not been fully elucidated in humans. In fact, it has been shown that incorrect dosage or route of administration of these phytochemicals may interfere with the activity of conventional therapies and result in harmful effects in humans [14,163].

Nanotechnology may offer a promising solution to these problems. Encapsulating polyphenols in nanoparticles could enhance their biodistribution, solubility, and stability in the human body, while reducing their intense metabolism. Moreover, conjugating nanoparticles containing a specific polyphenol with an appropriate anticancer drug may improve internalization of these natural compounds into cancer cells, leading to improved anticancer activity [164]. Several studies have reported that nanotechnology enhanced ability of CUR to counteract the growth of various tumors. Chang et al. found that CUR-loaded nanoparticles (Cur-NPs) selectively reduced the viability of cisplatin-resistant CAL-27 human oral cancer cells (CAR cells) in a dose- and time-dependent manner. Cur-NPs induced intrinsic apoptotic processes (up-regulating Bax, capsase-3, and caspase-9 synthesis and down-regulating expression of multiple drug resistance protein 1 (MDR1) and $\mathrm{Bcl}-2$ ) and enhanced ROS production in CAR cells [152]. 
Abouzeid et al. used a different combination to counteract the proliferation of HCT-116 cells. They investigated the therapeutic efficacy in vitro and in vivo of polymeric micelles targeted with an anti-GLUT1 (Glucose Transporter Type 1) antibody (GLUT1-PEG-PE micelles) and co-loaded with CUR and DOX. These micelles showed improved toxicity against HCT116 cells in vitro, even at low doses of DOX, compared to non-targeted micelles. Moreover, nude mice injected with HCT116 tumor cells, then treated with GLUT-1-PEG-PE micelles co-loaded with $4 \mathrm{mg} / \mathrm{kg}$ of CUR plus $0.4 \mathrm{mg} / \mathrm{kg}$ of DOX, displayed greater inhibition of tumor growth and improved survival compared to untreated mice and mice treated with targeted micelles co-loaded with CUR or DOX alone. These promising results suggest a role for these formulations in decreasing glucose uptake, suppressing GLUT1 protein activity, or enhancing delivery of CUR and DOX into colon cancer cells in vivo [153].

Similarly, methoxypoly(ethylene glycol)-poly(caprolactone) (MPEG-PCL) micelles loaded with CUR and DOX (Cur-Dox/MPEG-PCL) showed promising anticancer effects and few side effects in the treatment of lung cancer in vitro and in vivo. These micelles released CUR and DOX slowly into LL/2 and MS1 lung cancer cell lines. In addition, CUR potentiated the anticancer activity of DOX in a synergic manner, indicating a probable synergistic interaction between the two compounds. The ability of CUR-DOX/MPEG-PCL to suppress proliferation of LL/2 cells in vivo was investigated using C57 mice bearing LL/2 lung carcinomas. Mice intravenously injected with CUR-DOX/MPEG-PCL micelles containing $5 \mathrm{mg} / \mathrm{kg}$ of CUR and $5 \mathrm{mg} / \mathrm{kg}$ of DOX showed improved inhibition of tumor growth compared to mice treated with micelles containing CUR or DOX alone, indicating in vivo synergy between the two compounds. In summary, CUR plus DOX inhibited tumor growth by enhancing apoptosis and suppressing angiogenesis in lung cancer cells, suggesting the potential use of CUR-DOX/MPEG-PCL micelles to improve the treatment of lung cancer in humans [154].

Treatment with liposomal CUR plus cisplatin resulted in greater suppression of tumor growth compared to treatment with cisplatin alone in a murine model of HNSCC. This effect was due to the capacity of CUR and cisplatin to decrease cyclin D1 expression and modulate the NF- $\kappa \mathrm{B}$ pathway through reduction of $\mathrm{I} \kappa \mathrm{B} \alpha$, phospho-I $\mathrm{K} \mathrm{B} \alpha$, and IKK $\beta$ expression in HNSCC cells. Cisplatin caused cellular senescence by promoting the activation of $\mathrm{p} 53$ protein. These promising in vivo results suggest that, in clinical practice, CUR plus cisplatin could potentially reduce the side effects of cisplatin as well as the dose required to inhibit the growth of HNSCC [155].

Yallapu et al. investigated the effect CUR nanoparticles on cisplatin-resistant A2780CP ovarian cancer cells. To improve the pharmacokinetics of CUR in vivo, a nanoparticle formulation of CUR, conjugated with a monoclonal antibody specific for tumor cells (PLGA-Nano-Cur), was synthesized. PLGA-Nano-Cur particles showed potent antiproliferative activity in A2780CP ovarian cancer cells, supporting the hypothesis that these nanoparticles may enhance delivery of CUR to the tumor site and specifically sensitize chemo- and/or radioresistant cancer cells [156].

The anticancer effects of these polyphenols in combination with anticancer agents are summarized in Table 3.

\section{Perspective and Conclusions}

Polyphenols, compounds ubiquitously expressed in plants, have beneficial effects on human health, including anti-inflammatory, antimicrobial, antiviral, anticancer, and immunomodulatory activities [3-5]. 
Carcinogenesis is a multistep process triggered by genetic alterations that activate multiple signal transduction pathways and cause the progressive transformation of a normal cell into a cancer cell [9]. Signal transduction pathways involved in carcinogenesis often interact with each other, enhancing the oncogenic signals needed to acquire a malignant phenotype $[3,10]$. Cross-talk between the signaling pathways mediated by ErbB receptors, NF- $\mathrm{BB}$, and the HH/GLI cascade may be the key factor in neoplastic transformation [3].

Due to their ability to modulate the activity of multiple targets involved in carcinogenesis, polyphenols can inhibit the growth of cancer cells [3,90-93,95-97]. Yet despite promising results from in vitro studies, in clinical practice, the use of polyphenols as single anticancer agents is limited. This fact is mainly due to their poor bioavailability in the human body. In fact, polyphenols have a poor absorption and biodistribution, but a high metabolism and excretion in the human body, which might hinder the in vivo effects of single compounds and affect the effective dose delivered to cancer cells. Although methods for improving the bioavailability of polyphenols have advanced in the last 20 years [4], new strategies are needed to increase the efficacy of polyphenols as anticancer drugs.

One strategy may be to combine different polyphenols with each other, or to use polyphenols in combination with anticancer drugs. Multiple in vitro and in vivo studies have shown that combinations of polyphenols more effectively inhibit tumor growth than the compounds employed singly. In addition, numerous in vitro and in vivo studies have shown that polyphenols potentiate the effects of conventional therapies and may help to reduce the effective dose of chemotherapy drugs, overcome drug resistance, and reduce toxicities.

However, there are still only a few clinical trials regarding the use of polyphenols in combination with conventional therapies for cancer treatment. One probable reason could be the fact that metabolism, stability, interaction with other drugs, side effects and mechanisms of action of these plant derivatives have not been fully elucidated in humans. An incorrect administration of these phytochemicals may interfere with the activity of conventional therapies leading to harmful effects in humans $[14,163]$.

A promising solution to overcome these problems could be represented by nanotechnology. In this regard, several preclinical studies reported that the encapsulation of polyphenols in small nanoparticles enhanced their bioavailability and antitumor activity [152-156,164].

The development of nanotechnology to increase bioavailability and antitumoral activities of polyphenols and their synergistic and/or additive effects with conventional anticancer therapies may provide the starting point to improve the rationale for designing new clinical trials to be employed in cancer treatment.

\section{Acknowledgments}

The authors thank Bonnie L. Casey her editorial assistance.

\section{Author Contributions}

All authors of this paper have directly participated in the planning or drafting of this manuscript and have read and approved the final version submitted. 


\section{Conflicts of Interest}

The authors declare no conflict of interest.

\section{References}

1. Manach, C.; Scalbert, A.; Morand, C.; Rémésy, C.; Jiménez, L. Polyphenols: Food sources and bioavailability. Am. J. Clin. Nutr. 2004, 79, 727-747.

2. Scalbert, A.; Manach, C.; Morand, C.; Rémésy, C.; Jiménez, L. Dietary polyphenols and the prevention of diseases. Crit. Rev. Food Sci. Nutr. 2005, 45, 287-306.

3. Benvenuto, M.; Fantini, M.; Masuelli, L.; de Smaele, E.; Zazzeroni, F.; Tresoldi, I.; Calabrese, G.; Galvano, F.; Modesti, A.; Bei, R. Inhibition of ErbB receptors, Hedgehog and NF-kappaB signaling by polyphenols in cancer. Front. Biosci. (Landmark Ed.) 2013, 18, 1290-1310.

4. Marzocchella, L.; Fantini, M.; Benvenuto, M.; Masuelli, L.; Tresoldi, I.; Modesti, A.; Bei, R. Dietary flavonoids: Molecular mechanisms of action as anti- inflammatory agents. Recent Pat. Inflamm. Allergy Drug Discov. 2011, 5, 200-220.

5. Izzi, V.; Masuelli, L.; Tresoldi, I.; Sacchetti, P.; Modesti, A.; Galvano, F.; Bei, R. The effects of dietary flavonoids on the regulation of redox inflammatory networks. Front. Biosci. 2012, 17, 2396-2418.

6. Vallianou, N.G.; Evangelopoulos, A.; Schizas, N.; Kazazis, C. Potential anticancer properties and mechanisms of action of curcumin. Anticancer Res. 2015, 35, 645-651.

7. Lall, R.K.; Syed, D.N.; Adhami, V.M.; Khan, M.I.; Mukhtar, H. Dietary polyphenols in prevention and treatment of prostate cancer. Int. J. Mol. Sci. 2015, 16, 3350-3376.

8. Chiurchiù, V.; Maccarrone, M. Chronic inflammatory disorders and their redox control: From molecular mechanisms to therapeutic opportunities. Antioxid. Redox Signal. 2011, 15, 2605-2641.

9. Bertram, J.S. The molecular biology of cancer. Mol. Aspects Med. 2000, 21, 167-223.

10. Hanahan, D.; Weinberg, R.A. The hallmarks of cancer. Cell 2000, 100, 57-70.

11. Bei, R.; Masuelli, L.; Turriziani, M.; Li Volti, G.; Malaguarnera, M.; Galvano, F. Impaired expression and function of signaling pathway enzymes by anthocyanins: Role on cancer prevention and progression. Curr. Enzym. Inhib. 2009, 5, 184-197.

12. Bei, R.; Palumbo, C.; Masuelli, L.; Turriziani, M.; Frajese, G.V.; Li Volti, G.; Malaguarnera, M.; Galvano, F. Impaired expression and function of cancer-related enzymes by anthocyans: An update. Curr. Enzym. Inhib. 2012, 8, 2-21.

13. Kunnumakkara, A.B.; Anand, P.; Aggarwal, B.B. Curcumin inhibits proliferation, invasion, angiogenesis and metastasis of different cancers through interaction with multiple cell signaling proteins. Cancer Lett. 2008, 269, 199-225.

14. Mohan, A.; Narayanan, S.; Sethuraman, S.; Krishnan, U.M. Combinations of plant polyphenols $\&$ anti-cancer molecules: A novel treatment strategy for cancer chemotherapy. Anticancer Agents Med. Chem. 2013, 13, 281-295.

15. Crozier, A.; Jaganath, I.B.; Clifford, M.N. Dietary phenolics: Chemistry, bioavailability and effects on health. Nat. Prod. Rep. 2009, 26, 1001-1043. 
16. Williamson, G.; Manach, C. Bioavailability and bioefficacy of polyphenols in humans. II. Review of 93 intervention studies. Am. J. Clin. Nutr. 2005, 81, 243S-255S.

17. Di Carlo, G.; Mascolo, N.; Izzo, A.A.; Capasso, F. Flavonoids: Old and new aspects of a class of natural therapeutic drugs. Life Sci. 1999, 65, 337-353.

18. Beecher, G.R. Overview of dietary flavonoids: Nomenclature, occurrence and intake. J. Nutr. 2003, 133, 3248S-3254S.

19. Wang, L.S.; Stoner, G.D. Anthocyanins and their role in cancer prevention. Cancer Lett. 2008, 269, 281-290.

20. Tomas-Barberan, F.A.; Clifford, M.N. Flavanones, chalcones and dihydrochalcones-nature, occurrence and dietary burden. J. Food Sci. Agric. 2000, 80, 1073-1080.

21. Sakai, T.; Kogiso, M. Soy isoflavones and immunity. J. Med. Investig. 2008, 55, 167-173.

22. Cassidy, A.; Hanley, B.; Lamuela-Raventos, R.M. Isoflavones, lignans and stilbenes-origins, metabolism and potential importance to human health. J. Sci. Food Agric. 2000, 80, 1044-1062.

23. Bishayee, A. Cancer prevention and treatment with resveratrol: From rodent studies to clinical trials. Cancer Prev. Res. (Phila) 2009, 2, 409-418.

24. Goswami, S.K.; Das, D.K. Resveratrol and chemoprevention. Cancer Lett. 2009, 284, 1-6.

25. Kundu, J.K.; Surh, Y.J. Cancer chemopreventive and therapeutic potential of resveratrol: Mechanistic perspectives. Cancer Lett. 2008, 269, 243-261.

26. Rowland, I.; Faughnan, M.; Hoey, L.; Wähälä, K.; Williamson, G.; Cassidy, A. Bioavailability of phyto-oestrogens. Br. J. Nutr. 2003, 89, S45-S58.

27. Heinonen, S.; Nurmi, T.; Liukkonen, K.; Poutanen, K.; Wähälä, K.; Deyama, T.; Nishibe, S.; Adlercreutz, H. In vitro metabolism of plant lignans: New precursors of mammalian lignans enterolactone and enterodiol. J. Agric. Food Chem. 2001, 49, 3178-3186.

28. Prasad, S.; Tyagi, A.K.; Aggarwal, B.B. Recent developments in delivery, bioavailability, absorption and metabolism of curcumin: The golden pigment from golden spice. Cancer Res. Treat. 2014, 46, 2-18.

29. Masuelli, L.; Benvenuto, M.; Fantini, M.; Marzocchella, L.; Sacchetti, P.; di Stefano, E.; Tresoldi, I.; Izzi, V.; Bernardini, R.; Palumbo, C.; et al. Curcumin induces apoptosis in breast cancer cell lines and delays the growth of mammary tumors in neu transgenic mice. J. Biol. Regul. Homeost. Agents 2013, 27, 105-119.

30. Yarden, Y.; Sliwkowski, M.X. Untangling the ErbB signalling network. Nat. Rev. Mol. Cell. Biol. 2001, 2, 127-137.

31. McKay, M.M.; Morrison, D.K. Integrating signals from RTKs to ERK/MAPK. Oncogene 2007, 26, 3113-3321.

32. Squires, M.S.; Hudson, E.A.; Howells, L.; Sale, S.; Houghton, C.E.; Jones, J.L.; Fox, L.H.; Dickens, M.; Prigent, S.A.; Manson, M.M. Relevance of mitogen activated protein kinase (MAPK) and phosphotidylinositol-3-kinase/protein kinase B (PI3K/PKB) pathways to induction of apoptosis by curcumin in breast cells. Biochem. Pharmacol. 2003, 65, 361-376.

33. Sun, X.D.; Liu, X.E.; Huang, D.S. Curcumin induces apoptosis of triple-negative breast cancer cells by inhibition of EGFR expression. Mol. Med. Rep. 2012, 6, 1267-1270.

34. Sun, S.H.; Huang, H.C.; Huang, C., Lin, J.K. Cycle arrest and apoptosis in MDA-MB-231/Her2 cells induced by curcumin. Eur. J. Pharmacol. 2012, 690, 22-30. 
35. Cai, X.Z.; Wang, J.; Li, X.D.; Wang, G.L.; Liu, F.N.; Cheng, M.S.; Li, F. Curcumin suppresses proliferation and invasion in human gastric cancer cells by downregulation of PAK1 activity and cyclin D1 expression. Cancer Biol. Ther. 2009, 8, 1360-1368.

36. Thangapazham, R.L.; Shaheduzzaman, S.; Kim, K.H.; Passi, N.; Tadese, A.; Vahey, M.; Dobi, A.; Srivastava, S.; Maheshwari, R.K. Androgen responsive and refractory prostate cancer cells exhibit distinct curcumin regulated transcriptome. Cancer Biol. Ther. 2008, 7, 1427-1435.

37. Lev-Ari, S.; Starr, A.; Vexler, A.; Karaush, V.; Loew, V.; Greif, J.; Fenig, E.; Aderka, D.; Ben-Yosef, R. Inhibition of pancreatic and lung adenocarcinoma cell survival by curcumin is associated with increased apoptosis, down-regulation of COX-2 and EGFR and inhibition of Erk1/2 activity. Anticancer Res. 2006, 26, 4423-4430.

38. Watson, J.L.; Greenshields, A.; Hill, R.; Hilchie, A.; Lee, P.W.; Giacomantonio, C.A.; Hoskin, D.W. Curcumin-induced apoptosis in ovarian carcinoma cells is p53-independent and involves p38 mitogen-activated protein kinase activation and downregulation of $\mathrm{Bcl}-2$ and survivin expression and Akt signaling. Mol. Carcinog. 2010, 49, 13-24.

39. Pan, M.H.; Lin, C.C.; Lin, J.K.; Chen, W.J. Tea polyphenol (-)-epigallocatechin 3-gallate suppresses heregulin-betal-induced fatty acid synthase expression in human breast cancer cells by inhibiting phosphatidylinositol 3-kinase/Akt and mitogen-activated protein kinase cascade signaling. J. Agric. Food Chem. 2007, 55, 5030-5037.

40. Pianetti, S.; Guo, S.; Kavanagh, K.T.; Sonenshein, G.E. Green tea polyphenol epigallocatechin-3 gallate inhibits Her-2/neu signaling, proliferation, and transformed phenotype of breast cancer cells. Cancer Res. 2002, 62, 652-655.

41. Masuda, M.; Suzui, M.; Lim, J.T.; Deguchi, A.; Soh, J.W.; Weinstein, I.B. Epigallocatechin-3-gallate decreases VEGF production in head and neck and breast carcinoma cells by inhibiting EGFR-related pathways of signal transduction. J. Exp. Ther. Oncol. 2002, 2, 350-359.

42. Masuda, M.; Suzui, M.; Lim, J.T.; Weinstein, I.B. Epigallocatechin-3-gallate inhibits activation of HER-2/neu and downstream signaling pathways in human head and neck and breast carcinoma cells. Clin. Cancer Res. 2003, 9, 3486-3491.

43. Shimizu, M.; Deguchi, A.; Joe, A.K.; Mckoy, J.F.; Moriwaki, H.; Weinstein, I.B. EGCG inhibits activation of HER3 and expression of cyclooxygenase-2 in human colon cancer cells. J. Exp. Ther. Oncol. 2005, 5, 69-78.

44. Adachi, S.; Nagao, T.; Ingolfsson, H.; Maxfield, F.R.; Andersen, O.S.; Kopelovich, L.; Weinstein, I.B. The inhibitory effect of (-)-epigallocatechin gallate on activation of the epidermal growth factor receptor is associated with altered lipid order in HT29 colon cancer cells. Cancer Res. 2007, 67, 6493-6501.

45. Adachi, S.; Nagao, T.; To, S.; Joe, A.K.; Shimizu, M.; Matsushima-Nishiwaki, R.; Kozawa, O.; Moriwaki, H.; Maxfield, F.R.; Weinstein, I.B. (-)-Epigallocatechin gallate causes internalization of the epidermal growth factor receptor in human colon cancer cells. Carcinogenesis 2008, 29, 1986-1993.

46. Adachi, S.; Shimizu, M.; Shirakami, Y.; Yamauchi, J.; Natsume, H.; Matsushima-Nishiwaki R.; To, S.; Weinstein, I.B.; Moriwaki, H.; Kozawa, O. (-)-Epigallocatechin gallate downregulates EGF receptor via phosphorylation at Ser1046/1047 by p38 MAPK in colon cancer cells. Carcinogenesis 2009, 30, 1544-1552. 
47. Parekh, P.; Motiwale, L.; Naik, N.; Rao, K.V. Downregulation of cyclin D1 is associated with decreased levels of p38 MAP kinases, Akt/PKB and Pak1 during chemopreventive effects of resveratrol in liver cancer cells. Exp. Toxicol. Pathol. 2011, 63, 167-173.

48. Kim, A.L.; Zhu, Y.; Zhu, H.; Han, L.; Kopelovich, L.; Bickers, D.R.; Athar, M. Resveratrol inhibits proliferation of human epidermoid carcinoma A431 cells by modulating MEK1 and AP-1 signalling pathways. Exp. Dermatol. 2006, 15, 538-546.

49. Serra, D.; Rufino, A.T.; Mendes, A.F.; Almeida, L.M.; Dinis, T.C. Resveratrol modulates cytokine-induced Jak/STAT activation more efficiently than 5-aminosalicylic acid: An in vitro approach. PLOS ONE 2014, 9, e109048.

50. Jeong, J.H.; An, J.Y.; Kwon, Y.T.; Li, L.Y.; Lee, Y.J. Quercetin-induced ubiquitination and down-regulation of Her-2/neu. J. Cell. Biochem. 2008, 105, 585-595.

51. Granado-Serrano, A.B.; Martín, M.A.; Bravo, L.; Goya, L.; Ramos, S. Quercetin modulates NF-kappa B and AP-1/JNK pathways to induce cell death in human hepatoma cells. Nutr. Cancer 2010, 62, 390-401.

52. Nguyen, T.T.; Tran, E.; Nguyen, T.H.; Do, P.T.; Huynh, T.H.; Huynh, H. The role of activated MEK-ERK pathway in quercetin-induced growth inhibition and apoptosis in A549 lung cancer cells. Carcinogenesis 2004, 25, 647-659.

53. Shukla, S.; Gupta, S. Apigenin-induced cell cycle arrest is mediated by modulation of MAPK, PI3K-Akt, and loss of cyclin D1 associated retinoblastoma dephosphorylation in human prostate cancer cells. Cell Cycle 2007, 6, 1102-1114.

54. Long, X.; Fan, M.; Bigsby, R.M.; Nephew, K.P. Apigenin inhibits antiestrogen-resistant breast cancer cell growth through estrogen receptor-alpha-dependent and estrogen receptor-alphaindependent mechanisms. Mol. Cancer Ther. 2008, 7, 2096-2108.

55. Masuelli, L.; Marzocchella, L.; Quaranta, A.; Palumbo, C.; Pompa, G.; Izzi, V.; Canini, A.; Modesti, A.; Galvano, F.; Bei, R. Apigenin induces apoptosis and impairs head and neck carcinomas EGFR/ErbB2 signaling. Front. Biosci. (Landmark Ed.) 2011, 16, 1060-1068.

56. Lee, W.S.; Yi, S.M.; Yun, J.W.; Jung, J.H.; Kim, D.H.; Kim, H.J.; Chang, S.H.; Kim, G.; Ryu, C.H.; Shin, S.C.; et al. Polyphenols isolated from Allium cepa L. induces apoptosis by induction of p53 and suppression of Bcl-2 through inhibiting PI3K/Akt signaling pathway in AGS human cancer cells. J. Cancer Prev. 2014, 19, 14-22.

57. Gupta, S.; Hastak, K.; Afaq, F.; Ahmad, N.; Mukhtar, H. Essential role of caspases in epigallocatechin-3-gallate-mediated inhibition of nuclear factor kappa B and induction of apoptosis. Oncogene 2004, 23, 2507-2522.

58. Hafeez, B.B.; Siddiqui, I.A.; Asim, M.; Malik, A.; Afaq, F.; Adhami, V.M.; Saleem, M.; Din, M.; Mukhtar, H. A dietary anthocyanidin delphinidin induces apoptosis of human prostate cancer PC3 cells in vitro and in vivo: Involvement of nuclear factor-kappaB signaling. Cancer Res. 2008, 68, 8564-8572.

59. Hafeez, B.B.; Asim, M.; Siddiqui, I.A.; Adhami, V.M.; Murtaza, I.; Mukhtar, H. Delphinidin, a dietary anthocyanidin in pigmented fruits and vegetables: A new weapon to blunt prostate cancer growth. Cell Cycle 2008, 7, 3320-3326. 
60. Yun, J.M.; Afaq, F.; Khan, N.; Mukhtar, H. Delphinidin, an anthocyanidin in pigmented fruits and vegetables, induces apoptosis and cell cycle arrest in human colon cancer HCT116 cells. Mol. Carcinog. 2009, 48, 260-270.

61. Wang, L.S.; Hecht, S.S.; Carmella, S.G.; Yu, N.; Larue, B.; Henry, C.; McIntyre, C.; Rocha C.; Lechner, J.F.; Stoner, G.D. Anthocyanins in black raspberries prevent esophageal tumors in rats. Cancer Prev. Res. (Phila) 2009, 2, 84-93.

62. Fan, M.J.; Wang, I.C.; Hsiao, Y.T.; Lin, H.Y.; Tang, N.Y.; Hung, T.C.; Quan, C.; Lien, J.C.; Chung, J.G. Anthocyanins from black rice (Oryza sativa L.) demonstrate antimetastatic properties by reducing MMPs and NF- $\mathrm{B}$ expressions in human oral cancer CAL 27 cells. Nutr. Cancer 2015, 67, 327-338.

63. Chung, T.W.; Moon, S.K.; Chang, Y.C.; Ko, J.H.; Lee, Y.C.; Cho, G.; Kim, S.H.; Kim, J.G.; Kim, C.H. Novel and therapeutic effect of caffeic acid and caffeic acid phenyl ester on hepatocarcinoma cells: Complete regression of hepatoma growth and metastasis by dual mechanism. FASEB J. 2004, 18, 1670-1681.

64. Divya, C.S.; Pillai, M.R. Antitumor action of curcumin in human papillomavirus associated cells involves downregulation of viral oncogenes, prevention of NFkB and AP-1 translocation, and modulation of apoptosis. Mol. Carcinog. 2006, 45, 320-332.

65. Chun, K.S.; Keum, Y.S.; Han, S.S.; Song, Y.S.; Kim, S.H.; Surh, Y.J. Curcumin inhibits phorbol ester-induced expression of cyclooxygenase-2 in mouse skin through suppression of extracellular signal-regulated kinase activity and NF-kappaB activation. Carcinogenesis 2003, 24, 1515-1524.

66. Pozo-Guisado, E.; Merino, J.M.; Mulero-Navarro, S.; Lorenzo-Benayas, M.J.; Centeno, F.; Alvarez-Barrientos, A.; Fernandez-Salguero, P.M. Resveratrol-induced apoptosis in MCF-7 human breast cancer cells involves a caspase-independent mechanism with downregulation of Bcl-2 and NF-kappaB. Int. J. Cancer 2005, 115, 74-84.

67. Estrov, Z.; Shishodia, S.; Faderl, S.; Harris, D.; Van, Q.; Kantarjian, H.M.; Talpaz, M.; Aggarwal, B.B. Resveratrol blocks interleukin-1beta-induced activation of the nuclear transcription factor NF-kappaB, inhibits proliferation, causes S-phase arrest, and induces apoptosis of acute myeloid leukemia cells. Blood 2003, 102, 987-995.

68. Elamin, M.H.; Shinwari, Z.; Hendrayani, S.F.; Al-Hindi, H.; al-Shail, E.; Khafaga, Y.; al-Kofide, A.; Aboussekhra, A. Curcumin inhibits the Sonic Hedgehog signaling pathway and triggers apoptosis in medulloblastoma cells. Mol. Carcinog. 2010, 49, 302-314.

69. Tang, G.Q.; Yan, T.Q.; Guo, W.; Ren, T.T.; Peng, C.L.; Zhao, H.; Lu, X.C.; Zhao, F.L.; Han, X. (-)-Epigallocatechin-3-gallate induces apoptosis and suppresses proliferation by inhibiting the human Indian Hedgehog pathway in human chondrosarcoma cells. J. Cancer Res. Clin. Oncol. 2010, 136, 1179-1185.

70. Tang, S.N.; Fu, J.; Nall, D.; Rodova, M.; Shankar, S.; Srivastava, R.K. Inhibition of sonic hedgehog pathway and pluripotency maintaining factors regulate human pancreatic cancer stem cell characteristics. Int. J. Cancer 2012, 131, 30-40.

71. Zhang, L.; Li, L.; Jiao, M.; Wu, D.; Wu, K.; Li, X.; Zhu, G.; Yang, L.; Wang, X.; Hsieh, J.T.; et al. Genistein inhibits the stemness properties of prostate cancer cells through targeting Hedgehog-Gli1 pathway. Cancer Lett. 2012, 323, 48-57. 
72. Slusarz, A.; Shenouda, N.S.; Sakla, M.S.; Drenkhahn, S.K.; Narula, A.S.; MacDonald, R.S.; Besch-Williford, C.L.; Lubahn, D.B. Common botanical compounds inhibit the hedgehog signaling pathway in prostate cancer. Cancer Res. 2010, 70, 3382-3390.

73. Jacobs, M.D.; Harrison, S.C. Structure of an IkappaBalpha/NF-kappaB complex. Cell 1998, 95, 749-758.

74. Naugler, W.E.; Karin, M. NF-kappaB and cancer-identifying targets and mechanisms. Curr. Opin. Genet. Dev. 2008, 18, 19-26.

75. Sarkar, F.H.; Li, Y.; Wang, Z.; Kong, D. NF-kappaB signaling pathway and its therapeutic implications in human diseases. Int. Rev. Immunol. 2008, 27, 293-319.

76. Bei, R.; Masuelli, L.; Palumbo, C.; Modesti, M.; Modesti, A. A common repertoire of autoantibodies is shared by cancer and autoimmune disease patients: Inflammation in their induction and impact on tumor growth. Cancer Lett. 2009, 281, 8-23.

77. Sethi, G.; Sung, B.; Aggarwal, B.B. Nuclear factor-kappaB activation: From bench to bedside. Exp. Biol. Med. (Maywood) 2008, 233, 21-31.

78. Mimeault, M.; Johansson, S.L.; Henichart, J.P.; Depreux, P.; Batra, S.K. Cytotoxic effects induced by docetaxel, gefitinib, and cyclopamine on side population and nonside population cell fractions from human invasive prostate cancer cells. Mol. Cancer Ther. 2010, 9, 617-630.

79. Mangelberger, D.; Kern, D.; Loipetzberger, A.; Eberl, M.; Aberger, F. Cooperative Hedgehog-EGFR signaling. Front. Biosci. (Landmark Ed.) 2012, 17, 90-99.

80. Kubo, M.; Nakamura, M.; Tasaki, A.; Yamanaka, N.; Nakashima, H.; Nomura, M.; Kuroki, S.; Katano, M. Hedgehog signaling pathway is a new therapeutic target for patients with breast cancer. Cancer Res. 2004, 64, 6071-6074.

81. Stecca, B.; Mas, C.; Clement, V.; Zbinden, M.; Correa, R.; Piguet, V.; Beermann, F.; Ruiz, I.; Altaba, A. Melanomas require HEDGEHOG-GLI signaling regulated by interactions between GLI1 and the RAS-MEK/AKT pathways. Proc. Natl. Acad. Sci. USA 2007, 104, 5895-5900.

82. Riobó, N.A.; Haines, G.M.; Emerson, C.P., Jr. Protein kinase C-delta and mitogen-activated protein/extracellular signal-regulated kinase-1 control GLI activation in hedgehog signaling. Cancer Res. 2006, 66, 839-845.

83. Riobó, N.A.; Lu, K.; Ai, X.; Haines, G.M.; Emerson, C.P., Jr. Phosphoinositide 3-kinase and Akt are essential for Sonic Hedgehog signaling. Proc. Natl. Acad. Sci. USA 2006, 103, 4505-4510.

84. Schnidar, H.; Eberl, M.; Klingler, S.; Mangelberger, D.; Kasper, M.; Hauser-Kronberger, C.; Regl, G.; Kroismayr, R.; Moriggl, R.; Sibilia, M.; et al. Epidermal growth factor receptor signaling synergizes with Hedgehog/GLI in oncogenic transformation via activation of the MEK/ERK/JUN pathway. Cancer Res. 2009, 69, 1284-1292.

85. Seto, M.; Ohta, M.; Asaoka, Y.; Ikenoue, T.; Tada, M.; Miyabayashi, K.; Mohri, D.; Tanaka, Y.; Ijichi, H.; Tateishi, K.; et al. Regulation of the hedgehog signaling by the mitogen-activated protein kinase cascade in gastric cancer. Mol. Carcinog. 2009, 48, 703-712.

86. Merkhofer, E.C.; Cogswell, P.; Baldwin, A.S. Her2 activates NF-kappaB and induces invasion through the canonical pathway involving IKKalpha. Oncogene 2010, 29, 1238-1248.

87. Liu, M.; Ju, X.; Willmarth, N.E.; Casimiro, M.C.; Ojeifo, J.; Sakamaki, T.; Katiyar, S.; Jiao, X.; Popov, V.M.; Yu, Z.; et al. Nuclear factor-kappaB enhances ErbB2-induced mammary tumorigenesis and neoangiogenesis in vivo. Am. J. Pathol. 2009, 174, 1910-1920. 
88. Cao, Y.; Luo, J.L.; Karin, M. IkappaB kinase alpha kinase activity is required for self-renewal of ErbB2/Her2-transformed mammary tumor-initiating cells. Proc. Natl. Acad. Sci. USA 2007, 104, $15852-15857$.

89. Makino, K.; Day, C.P.; Wang, S.C.; Li, Y.M.; Hung, M.C. Upregulation of IKKalpha/IKKbeta by integrin-linked kinase is required for HER2/neu-induced NF-kappaB antiapoptotic pathway. Oncogene 2004, 23, 3883-3887.

90. Elledge, S.J. Cell cycle checkpoints: Preventing an identity crisis. Science 1996, 274, 1664-1672.

91. Levine, A.J. p53, the cellular gatekeeper for growth and division. Cell 1997, 88, 323-331.

92. Lowe, S.W.; Ruley, H.E.; Jacks, T.; Housman, D.E. p53-dependent apoptosis modulates the cytotoxicity of anticancer agents. Cell 1993, 74, 957-867.

93. Aas, T.; Børresen, A.L.; Geisler, S.; Smith-Sørensen, B.; Johnsen, H.; Varhaug, J.E.; Akslen, L.A.; Lønning, P.E. Specific P53 mutations are associated with de novo resistance to doxorubicin in breast cancer patients. Nat. Med. 1996, 2, 811-814.

94. Geisler, S.; Børresen-Dale, A.L.; Johnsen, H.; Aas, T.; Geisler, J.; Akslen L.A.; Anker, G.; Lønning, P.E. TP53 gene mutations predict the response to neoadjuvant treatment with 5-fluorouracil and mitomycin in locally advanced breast cancer. Clin. Cancer Res. 2003, 9, 5582-5588.

95. Plati, J.; Bucur, O.; Khosravi-Far, R. Apoptotic cell signaling in cancer progression and therapy. Integr. Biol. (Camb.) 2011, 3, 279-296.

96. Cavallaro, U.; Christofori, G. Molecular mechanisms of tumor angiogenesis and tumor progression. J. Neurooncol. 2000, 50, 63-70.

97. Hahnfeldt, P.; Panigrahy, D.; Folkman, J.; Hlatky, L. Tumor development under angiogenic signaling: A dynamical theory of tumor growth, treatment response, and postvascular dormancy. Cancer Res. 1999, 59, 4770-4775.

98. Alesiani, D.; Cicconi, R.; Mattei, M.; Montesano, C.; Bei, R.; Canini, A. Cell cycle arrest and differentiation induction by 5,7-dimethoxycoumarin in melanoma cell lines. Int. J. Oncol. 2008, 32, 425-434.

99. Alesiani, D.; Cicconi, R.; Mattei, M.; Bei, R.; Canini, A. Inhibition of Mek 1/2 kinase activity and stimulation of melanogenesis by 5,7-dimethoxycoumarin treatment of melanoma cells. Int. J. Oncol. 2009, 34, 1727-1735.

100. Renis, M.; Calandra, L.; Scifo, C.; Tomasello, B.; Cardile, V.; Vanella, L.; Bei, R.; la Fauci, L.; Galvano, F. Response of cell cycle/stress-related protein expression and DNA damage upon treatment of $\mathrm{CaCo} 2$ cells with anthocyanins. Br. J. Nutr. 2008, 100, 27-35.

101. Manach, C.; Williamson, G.; Morand, C.; Scalbert, A.; Rémésy, C. Bioavailability and bioefficacy of polyphenols in humans. I. Review of 97 bioavailability studies. Am. J. Clin. Nutr. 2005, 81, 230S-242S.

102. Scalbert, A.; Williamson, G. Dietary intake and bioavailability of polyphenols. J. Nutr. 2000, 130, 2073S-2085S.

103. Ginsburg, I.; Kohen, R.; Koren, E. Microbial and host cells acquire enhanced oxidant-scavenging abilities by binding polyphenols. Arch. Biochem. Biophys. 2011, 506, 12-23.

104. Bohn, T. Dietary factors affecting polyphenol bioavailability. Nutr. Rev. 2014, 72, 429-452. 
105. Ferrer, P.; Asensi, M.; Segarra, R.; Ortega, A.; Benlloch, M.; Obrador, E.; Varea, M.T.; Asensio, G.; Jordá, L.; Estrela, J.M. Association between pterostilbene and quercetin inhibits metastatic activity of B16 melanoma. Neoplasia 2005, 7, 37-47.

106. Sakamoto, K. Synergistic effects of thearubigin and genistein on human prostate tumor cell (PC-3) growth via cell cycle arrest. Cancer Lett. 2000, 151, 103-109.

107. Harper, C.E.; Cook, L.M.; Patel, B.B.; Wang, J.; Eltoum, I.A.; Arabshahi, A.; Shirai, T.; Lamartiniere, C.A. Genistein and resveratrol, alone and in combination, suppress prostate cancer in SV-40 tag rats. Prostate 2009, 69, 1668-1682.

108. Wang, P.; Heber, D.; Henning, S.M. Quercetin increased the antiproliferative activity of green tea polyphenol (-)-epigallocatechin gallate in prostate cancer cells. Nutr. Cancer 2012, 64, $580-587$.

109. Wang, P.; Vadgama, J.V.; Said, J.W.; Magyar, C.E.; Doan, N.; Heber, D.; Henning S.M. Enhanced inhibition of prostate cancer xenograft tumor growth by combining quercetin and green tea. J. Nutr. Biochem. 2014, 25, 73-80.

110. Zhou, D.H.; Wang, X.; Yang, M.; Shi, X.; Huang, W.; Feng, Q. Combination of low concentration of (-)-epigallocatechin gallate (EGCG) and curcumin strongly suppresses the growth of non-small cell lung cancer in vitro and in vivo through causing cell cycle arrest. Int. J. Mol. Sci. 2013, 14, 12023-12036.

111. Somers-Edgar, T.J.; Scandlyn, M.J.; Stuart, E.C.; le Nedelec, M.J.; Valentine, S.P.; Rosengren, R.J. The combination of epigallocatechin gallate and curcumin suppresses ER alpha-breast cancer cell growth in vitro and in vivo. Int. J. Cancer 2008, 122, 1966-1971.

112. Wang, P.; Wang, B.; Chung, S.; Wu, Y.; Henning, S.M.; Vadgama, J.V. Increased chemopreventive effect by combining arctigenin, green tea polyphenol and curcumin in prostate and breast cancer cells. RSC Adv. 2014, 4, 35242-35250.

113. Amin, A.R.; Wang, D.; Zhang, H.; Peng, S.; Shin, H.J.; Brandes, J.C.; Tighiouart, M.; Khuri, F.R.; Chen, Z.G.; Shin, D.M. Enhanced anti-tumor activity by the combination of the natural compounds (-)-epigallocatechin-3-gallate and luteolin: Potential role of p53. J. Biol. Chem. 2010, 285, 34557-34665.

114. Mertens-Talcott, S.U.; Talcott, S.T.; Percival, S.S. Low concentrations of quercetin and ellagic acid synergistically influence proliferation, cytotoxicity and apoptosis in MOLT-4 human leukemia cells. J. Nutr. 2003, 133, 2669-2774.

115. Mertens-Talcott, S.U.; Percival, S.S. Ellagic acid and quercetin interact synergistically with resveratrol in the induction of apoptosis and cause transient cell cycle arrest in human leukemia cells. Cancer Lett. 2005, 218, 141-151.

116. Liontas, A.; Yeger, H. Curcumin and resveratrol induce apoptosis and nuclear translocation and activation of p53 in human neuroblastoma. Anticancer Res. 2004, 24, 987-998.

117. Masuelli, L.; Marzocchella, L.; Focaccetti, C.; Tresoldi, I.; Palumbo, C.; Izzi, V.; Benvenuto, M.; Fantini, M.; Lista, F.; Tarantino, U.; et al. Resveratrol and diallyl disulfide enhance curcumin-induced sarcoma cell apoptosis. Front. Biosci. (Landmark Ed.) 2012, 17, 498-508. 
118. Masuelli, L.; di Stefano, E.; Fantini, M.; Mattera, R.; Benvenuto, M.; Marzocchella, L.; Sacchetti, P.; Focaccetti, C.; Bernardini, R.; Tresoldi, I.; et al. Resveratrol potentiates the in vitro and in vivo anti-tumoral effects of curcumin in head and neck carcinomas. Oncotarget 2014, 5, 10745-10762.

119. Elattar, T.M.; Virji, A.S. The effect of red wine and its components on growth and proliferation of human oral squamous carcinoma cells. Anticancer Res. 1999, 19, 5407-5414.

120. Majumdar, A.P.; Banerjee, S.; Nautiyal, J.; Patel, B.B.; Patel, V.; Du, J.; Yu, Y.; Elliott, A.A.; Levi, E.; Sarkar, F.H. Curcumin synergizes with resveratrol to inhibit colon cancer. Nutr. Cancer 2009, 61, 544-553.

121. Chan, M.M.; Fong, D. Overcoming drug resistance by phytochemicals. In Drug Resistance in Cancer Cells; Metha, K., Bates, S.E., Siddik, Z.H., Eds.; Springer Science+Business Media, LLC: New York, NY, USA, 2009; pp. 315-342.

122. Shakibaei, M.; Mobasheri, A.; Lueders, C.; Busch, F.; Shayan, P.; Goel, A. Curcumin enhances the effect of chemotherapy against colorectal cancer cells by inhibition of NF- $\kappa \mathrm{B}$ and Src protein kinase signaling pathways. PLoS ONE 2013, 8, e57218.

123. Abuzeid, W.M.; Davis, S.; Tang, A.L.; Saunders, L.; Brenner, J.C.; Lin, J.; Fuchs, J.R.; Light, E.; Bradford, C.R.; Prince, M.E.; et al. Sensitization of head and neck cancer to cisplatin through the use of a novel curcumin analog. Arch. Otolaryngol. Head Neck Surg. 2011, 137, 499-507.

124. Lev-Ari, S.; Vexler, A.; Starr, A.; Ashkenazy-Voghera, M.; Greif, J.; Aderka, D.; Ben-Yosef, R. Curcumin augments gemcitabine cytotoxic effect on pancreatic adenocarcinoma cell lines. Cancer Investig. 2007, 25, 411-418.

125. Kunnumakkara, A.B.; Guha, S.; Krishnan, S.; Diagaradjane, P.; Gelovani, J.; Aggarwal, B.B. Curcumin potentiates antitumor activity of gemcitabine in an orthotopic model of pancreatic cancer through suppression of proliferation, angiogenesis, and inhibition of nuclear factor-kappaB-regulated gene products. Cancer Res. 2007, 67, 3853-3861.

126. Lev-Ari, S.; Zinger, H.; Kazanov, D.; Yona, D.; Ben-Yosef, R.; Starr, A.; Figer, A.; Arber, N. Curcumin synergistically potentiates the growth inhibitory and pro-apoptotic effects of celecoxib in pancreatic adenocarcinoma cells. Biomed. Pharmacother. 2005, 59, S276-S280.

127. Veeraraghavan, J.; Natarajan, M.; Lagisetty, P.; Awasthi, V.; Herman, T.S.; Aravindan, N. Impact of curcumin, raspberry extract, and neem leaf extract on rel protein-regulated cell death/ radiosensitization in pancreatic cancer cells. Pancreas 2011, 40, 1107-1119.

128. Kamat, A.M.; Tharakan, S.T.; Sung, B.; Aggarwal, B.B. Curcumin potentiates the antitumor effects of Bacillus Calmette-Guerin against bladder cancer through the downregulation of NF-kappaB and upregulation of TRAIL receptors. Cancer Res. 2009, 69, 8958-8966.

129. Kang, H.J.; Lee, S.H.; Price, J.E.; Kim, L.S. Curcumin suppresses the paclitaxel-induced nuclear factor-kappaB in breast cancer cells and potentiates the growth inhibitory effect of paclitaxel in a breast cancer nude mice model. Breast J. 2009, 15, 223-229.

130. Singh, N.; Zaidi, D.; Shyam, H.; Sharma, R.; Balapure, A.K. Polyphenols sensitization potentiates susceptibility of MCF-7 and MDA MB-231 cells to Centchroman. PLoS ONE 2012, 7, e37736. 
131. Harikumar, K.B.; Kunnumakkara, A.B.; Sethi, G.; Diagaradjane, P.; Anand, P.; Pandey, M.K.; Gelovani, J.; Krishnan, S.; Guha, S.; Aggarwal B.B. Resveratrol, a multitargeted agent, can enhance antitumor activity of gemcitabine in vitro and in orthotopic mouse model of human pancreatic cancer. Int. J. Cancer 2010, 127, 257-268.

132. He, X.; Wang, Y.; Zhu, J.; Orloff, M.; Eng, C. Resveratrol enhances the anti-tumor activity of the mTOR inhibitor rapamycin in multiple breast cancer cell lines mainly by suppressing rapamycin-induced AKT signaling. Cancer Lett. 2011, 301, 168-176.

133. Aires, V.; Limagne, E.; Cotte, A.K.; Latruffe, N.; Ghiringhelli, F.; Delmas, D. Resveratrol metabolites inhibit human metastatic colon cancer cells progression and synergize with chemotherapeutic drugs to induce cell death. Mol. Nutr. Food Res. 2013, 57, 1170-1181.

134. Menendez, J.A.; Vazquez-Martin, A.; Colomer, R.; Brunet, J.; Carrasco-Pancorbo, A.; Garcia-Villalba, R.; Fernandez-Gutierrez, A.; Segura-Carretero, A. Olive oil's bitter principle reverses acquired autoresistance to trastuzumab (Herceptin) in HER2-overexpressing breast cancer cells. BMC Cancer 2007, 7, 80.

135. Suganuma, M.; Okabe, S.; Kai, Y.; Sueoka, N.; Sueoka, E.; Fujiki, H. Synergistic effects of (-)-epigallocatechin gallate with (-)-epicatechin, sulindac, or tamoxifen on cancer-preventive activity in the human lung cancer cell line PC-9. Cancer Res. 1999, 59, 44-47.

136. Suganuma, M.; Kurusu, M.; Suzuki, K.; Tasaki, E.; Fujiki, H. Green tea polyphenol stimulates cancer preventive effects of celecoxib in human lung cancer cells by upregulation of GADD153 gene. Int. J. Cancer 2006, 119, 33-40.

137. Adhami, V.M.; Malik, A.; Zaman, N.; Sarfaraz, S.; Siddiqui, I.A.; Syed, D.N.; Afaq, F.; Pasha, F.S.; Saleem, M.; Mukhtar, H. Combined inhibitory effects of green tea polyphenols and selective cyclooxygenase-2 inhibitors on the growth of human prostate cancer cells both in vitro and in vivo. Clin. Cancer Res. 2007, 13, 1611-1619.

138. Stearns, M.E.; Wang, M. Synergistic effects of the green tea extract epigallocatechin-3-gallate and taxane in eradication of malignant human prostate tumors. Transl. Oncol. 2011, 4, 147-156.

139. Stearns, M.E.; Amatangelo, M.D.; Varma, D.; Sell, C.; Goodyear, S.M. Combination therapy with epigallocatechin-3-gallate and doxorubicin in human prostate tumor modeling studies: Inhibition of metastatic tumor growth in severe combined immunodeficiency mice. Am. J. Pathol. 2010, 177, 3169-3179.

140. Chen, L.; Ye, H.L.; Zhang, G.; Yao, W.M.; Chen, X.Z.; Zhang, F.C.; Liang, G. Autophagy inhibition contributes to the synergistic interaction between EGCG and doxorubicin to kill the hepatoma Hep3B cells. PLoS ONE 2014, 9, e85771.

141. Liang, G.; Tang, A.; Lin, X.; Li, L.; Zhang, S.; Huang, Z.; Tang, H.; Li, Q.Q. Green tea catechins augment the antitumor activity of doxorubicin in an in vivo mouse model for chemoresistant liver cancer. Int. J. Oncol. 2010, 37, 111-123.

142. Luo, T.; Wang, J.; Yin, Y.; Hua, H.; Jing, J.; Sun, X.; Li, M.; Zhang, Y.; Jiang, Y. (-)-Epigallocatechin gallate sensitizes breast cancer cells to paclitaxel in a murine model of breast carcinoma. Breast Cancer Res. 2010, 12, R8.

143. Chan, M.M.; Soprano, K.J.; Weinstein, K.; Fong, D. Epigallocatechin-3-gallate delivers hydrogen peroxide to induce death of ovarian cancer cells and enhances their cisplatin susceptibility. J. Cell Physiol. 2006, 207, 389-396. 
144. Tang, S.N.; Fu, J.; Shankar, S.; Srivastava, R.K. EGCG enhances the therapeutic potential of gemcitabine and CP690550 by inhibiting STAT3 signaling pathway in human pancreatic cancer. PLoS ONE 2012, 7, e31067.

145. Staedler, D.; Idrizi, E.; Kenzaoui, B.H.; Juillerat-Jeanneret, L. Drug combinations with quercetin: Doxorubicin plus quercetin in human breast cancer cells. Cancer Chemother. Pharmacol. 2011, $68,1161-1172$.

146. Kuhar, M.; Sen, S.; Singh, N. Role of mitochondria in quercetin-enhanced chemotherapeutic response in human non-small cell lung carcinoma H-520 cells. Anticancer Res. 2006, 26, 1297-1303.

147. Sharma, H.; Sen, S.; Singh, N. Molecular pathways in the chemosensitization of cisplatin by quercetin in human head and neck cancer. Cancer Biol. Ther. 2005, 4, 949-955.

148. Mohammad, R.M.; Banerjee, S.; Li, Y.; Aboukameel, A.; Kucuk, O.; Sarkar, F.H. Cisplatin-induced antitumor activity is potentiated by the soy isoflavone genistein in BxPC-3 pancreatic tumor xenografts. Cancer 2006, 106, 1260-1268.

149. Banerjee, S.; Zhang, Y.; Wang, Z.; Che, M.; Chiao, P.J.; Abbruzzese, J.L.; Sarkar, F.H. In vitro and in vivo molecular evidence of genistein action in augmenting the efficacy of cisplatin in pancreatic cancer. Int. J. Cancer 2007, 120, 906-917.

150. Banerjee, S.; Zhang, Y.; Ali, S.; Bhuiyan, M.; Wang, Z.; Chiao, P.J.; Philip, P.A.; Abbruzzese, J.; Sarkar, F.H. Molecular evidence for increased antitumor activity of gemcitabine by genistein in vitro and in vivo using an orthotopic model of pancreatic cancer. Cancer Res. 2005, 65, 9064-9072.

151. Raffoul, J.J.; Banerjee, S.; Che, M.; Knoll, Z.E.; Doerge, D.R.; Abrams, J.; Kucuk, O.; Sarkar, F.H.; Hillman, G.G. Soy isoflavones enhance radiotherapy in a metastatic prostate cancer model. Int. J. Cancer 2007, 120, 2491-2498.

152. Chang, P.Y.; Peng, S.F.; Lee, C.Y.; Lu, C.C.; Tsai, S.C.; Shieh, T.M.; Wu, T.S.; Tu, M.G.; Chen, M.Y.; Yang, J.S. Curcumin-loaded nanoparticles induce apoptotic cell death through regulation of the function of MDR1 and reactive oxygen species in cisplatin-resistant CAR human oral cancer cells. Int. J. Oncol. 2013, 43, 1141-1150.

153. Abouzeid, A.H.; Patel, N.R.; Rachman, I.M.; Senn, S.; Torchilin, V.P. Anti-cancer activity of anti-GLUT1 antibody-targeted polymeric micelles co-loaded with curcumin and doxorubicin. J. Drug Target. 2013, 21, 994-1000.

154. Wang, B.L.; Shen, Y.M.; Zhang, Q.W.; Li, Y.L.; Luo, M.; Liu, Z.; Li, Y.; Qian, Z.Y.; Gao, X.; Shi, H.S. Codelivery of curcumin and doxorubicin by MPEG-PCL results in improved efficacy of systemically administered chemotherapy in mice with lung cancer. Int. J. Nanomed. 2013, 8, 3521-3531.

155. Duarte, V.M.; Han, E.; Veena, M.S.; Salvado, A.; Suh, J.D.; Liang, L.J.; Faull, K.F.; Srivatsan, E.S.; Wang, M.B. Curcumin enhances the effect of cisplatin in suppression of head and neck squamous cell carcinoma via inhibition of IKKbeta protein of the NFkappaB pathway. Mol. Cancer Ther. 2010, 9, 2665-2675.

156. Yallapu, M.M.; Maher, D.M.; Sundram, V.; Bell, M.C.; Jaggi, M.; Chauhan, S.C. Curcumin induces chemo/radio-sensitization in ovarian cancer cells and curcumin nanoparticles inhibit ovarian cancer cell growth. J. Ovarian Res. 2010, 3, 11. 
157. Russo, M.; Spagnuolo, C.; Tedesco, I.; Russo, G.L. Phytochemicals in cancer prevention and therapy: Truth or dare? Toxins (Basel) 2010, 2, 517-551.

158. Saldanha, S.N.; Tollefsbol, T.O. The role of nutraceuticals in chemoprevention and chemotherapy and their clinical outcomes. J. Oncol. 2012, 2012, 192464.

159. Kanwar, J.; Taskeen, M.; Mohammad, I.; Huo, C.; Chan, T.H.; Dou, Q.P. Recent advances on tea polyphenols. Front. Biosci. (Elite Ed.) 2012, 4, 111-131.

160. Gupta, S.C.; Patchva, S.; Aggarwal, B.B. Therapeutic roles of curcumin: Lessons learned from clinical trials. AAPS J. 2013, 15, 195-218.

161. Bayet-Robert, M.; Kwiatkowski, F.; Leheurteur, M.; Gachon, F.; Planchat, E.; Abrial, C.; Mouret-Reynier, M.A.; Durando, X.; Barthomeuf, C.; Chollet, P. Phase I dose escalation trial of docetaxel plus curcumin in patients with advanced and metastatic breast cancer. Cancer Biol. Ther. 2010, 9, 8-14.

162. Zhang, G.; Wang, Y.; Zhang, Y.; Wan, X.; Li, J.; Liu, K.; Wang, F.; Liu, K.; Liu, Q.; Yang, C.; et al. Anti-cancer activities of tea epigallocatechin-3-gallate in breast cancer patients under radiotherapy. Curr. Mol. Med. 2012, 12, 163-176.

163. Ulbricht, C.E.; Chao, W. Phytochemicals in the oncology setting. Curr. Treat. Opt. Oncol. 2010, 11, 95-106.

164. Tabrez, S.; Priyadarshini, M.; Urooj, M.; Shakil, S.; Ashraf, G.M.; Khan, M.S.; Kamal, M.A.; Alam, Q.; Jabir, N.R.; Abuzenadah, A.M.; et al. Cancer chemoprevention by polyphenols and their potential application as nanomedicine. J. Environ. Sci. Health C Environ. Carcinog. Ecotoxicol. Rev. 2013, 31, 67-98.

(C) 2015 by the authors; licensee MDPI, Basel, Switzerland. This article is an open access article distributed under the terms and conditions of the Creative Commons Attribution license (http://creativecommons.org/licenses/by/4.0/). 